\title{
Speculation and the Design of Development
}

\author{
PHOEBE SENGERS, Cornell University, USA \\ KAITON WILLIAMS, Impact America Fund, USA \\ VERA KHOVANSKAYA, University of California at San Diego, USA
}

This paper examines the role of technoscientific speculation in large-scale development projects in postcolonial spaces, building on recent work in STS, design research, and postcolonial studies in and beyond CSCW. We analyze two historical cases of technology-infused development projects in the Canadian province of Newfoundland and Labrador and in Jamaica. We find that speculation in these contexts remixes the constructive stance toward speculation typical for normative technoscience with the critical, contesting orientation of speculative design. Conflicts between these stances are resolved by leveraging fantasy for pragmatic ends, grounding audacious fictions in imported realities, unmooring from conventional understandings of linear technological progress, and using even conservative futures to trouble colonial conventions.

CCS Concepts: • Human-centered computing $\rightarrow$ Field studies; Empirical studies in interaction design; Interaction design theory, concepts and paradigms.

Additional Key Words and Phrases: speculation; speculative design; futures; postcolonial computing; history; Jamaica; Newfoundland and Labrador; development

\section{ACM Reference Format:}

Phoebe Sengers, Kaiton Williams, and Vera Khovanskaya. 2021. Speculation and the Design of Development. Proc. ACM Hum.-Comput. Interact. 5, CSCW1, Article 121 (April 2021), 27 pages. https://doi.org/10.1145/3449195

\section{INTRODUCTION}

I live in times far more interesting, complex, and thought provoking than any fictional future that critical designers have to offer. For myself and my colleagues [here in India], the future suggests itself in the contours of the problems and crises that we face every day in the problems of the present - the future is fluid and complex, it is open, not bound by any particular taste regime, it is political and bound up with the project of our emancipation and freedom. For us, futuring is critical because futuring is the way forward dealing with the critical problems of the now. - Ahmed Ansari [9]

Speculative visions of future sociotechnical worlds are a core driver of contemporary technoscientific practice. Such speculation is attracting interest across scholarly communities. Science $\&$ Technology (STS) scholars examine how speculative visions of technoscience motivate actors and justify the expenditure of corporate or national resources [84, 113, 121, 129]. Anthropologists analyze the downstream effects of such speculation on broader audiences $[1,142,176]$. Design

Authors' addresses: Phoebe Sengers, Cornell University, Information Science, Gates Hall, Ithaca, NY, 14853, USA, sengers@infosci.cornell.edu; Kaiton Williams, Impact America Fund, P.O. Box 1212, Dublin, Ohio, 43017-6221, USA, kaiton@impactamericafund.com; Vera Khovanskaya, University of California at San Diego, 9500 Gilman Dr. La Jolla, CA, 92093, USA, vkhovanskaya@ucsd.edu.

Permission to make digital or hard copies of all or part of this work for personal or classroom use is granted without fee provided that copies are not made or distributed for profit or commercial advantage and that copies bear this notice and the full citation on the first page. Copyrights for components of this work owned by others than the author(s) must be honored Abstracting with credit is permitted. To copy otherwise, or republish, to post on servers or to redistribute to lists, requires prior specific permission and/or a fee. Request permissions from permissions@acm.org.

(c) 2021 Copyright held by the owner/author(s). Publication rights licensed to ACM.

2573-0142/2021/4-ART121 \$15.00

https://doi.org/10.1145/3449195

Proc. ACM Hum.-Comput. Interact., Vol. 5, No. CSCW1, Article 121. Publication date: April 2021. 
researchers develop strategies to support technoscientific speculation [42, 98, 197], while also leveraging speculation to criticize contemporary visions of technological development [12, 70, 71]

Across this work, technoscientific speculation is often framed as authored by Western elites: the engineers and scientists who author ambitious visions for the future [113,129,141, 155] or academic product designers whose training renders them uniquely capable of imagining alternative visions to standard futures $[12,70,71]$. But a growing literature examines technoscientific speculation from the perspective of the Global South [54, 55, 97, 142, 164, 176]. In CSCW, this work examines how technology makers [15, 117, 139], state actors [82, 140], and citizen publics [82] are using contemporary technological projects as sites to collaboratively construct alternative national futures.

In this paper we explore how understandings of technoscientific speculation shift when we center speculation by actors in the global periphery in our analysis. Prior work in postcolonial computing $[118,165]$ has made clear that innovation in the Global South takes on different forms than those valorized in the Global North, such as through repair rather than only invention $[3,119]$ To analyze how technoscientific speculation is shaped in the Global South, we cross-inform STS, speculative design, and postcolonial studies, in conversation with related work in CSCW. STS provides tools for understanding speculation and future-making as performative practices shaping national futures [84, 120, 121, 129]. Speculative design as a form of design research provides tactics for using speculation to find alternatives to established futures and analyzes the mechanisms by which such tactics work $[12,18,60,66,70,71,80,85,103,171,210]$. Both STS and speculative design provide important conceptual insights and analytic lenses for understanding speculation, but focus largely on Western cases. In contrast, postcolonial studies, both in $[82,117,139,140]$ and beyond CSCW [54, 55, 142], demonstrates how stakeholders in the Global South are repurposing speculation to stake their own claims for alternative futures. By cross-informing these literatures, we aim to better illuminate the nature of speculation from the periphery.

We organize our analysis around two historical case studies of development projects in postcolonial island states: the nation-state of Jamaica and the Canadian province of Newfoundland and Labrador. The political leadership of both British ex-colonies invested heavily in state-sponsored projects that leveraged technological imaginaries of potential modern, developed futures. Their projections were bold, uncertain, and never realized. We approach these projects as forms of speculation on the periphery and analyze how states leveraged speculation to try to create a better future for their citizens. We examine why it was leveraged given the serious pragmatic problems these states faced, how this was done, and how the tactics promoted by speculative design play out differently within the uneven power dynamics that characterize postcolonial contexts.

The core contribution of our paper is to show that speculation on the periphery must navigate a tension between two conflicting orientations to technoscientific speculation. STS often frames speculation as a core mechanism of normative technoscientific development. Speculative design instead frames it as a critical alternative to that practice. Our cases reveal that these stances are intermingled on the periphery. As in STS, actors actively leverage speculation to generate apparently plausible new economic trajectories. But, as in speculative design, their speculations question longstanding narratives about how technology produces presents and futures. The clashing frames of these orientations lead to an innovative remix on the periphery, prompting stakeholders to leverage fantasy for pragmatic ends, ground audacious fictions in imported realities, unmoor from conventional understandings of linear technological progress, and use apparently conservative strategies to contest the center's narratives.

In the next section, we describe how these two different views on speculation emerge from the literature, and how views of speculation are changing because of emerging work on speculation in the Global South. Then, we describe the forms and outcomes of speculation in our two historical 
cases. Finally, we show how these approaches to speculation draw from and remix tactics of speculation used in both normative technoscience and critical alternatives to it, in response to specific conditions that arise because of these states' location on the periphery.

\section{SPECULATION AND ITS DISCONTENTS}

In this paper, we understand speculation as the creative articulation of imaginary but coherent future sociotechnical worlds, and the leveraging of those worlds to inform present-day action. Adams, Murphy and Clarke influentially argue that anticipation, i.e. an affective state of living towards speculative futures, has become a central feature of contemporary life [1]. It is perhaps no surprise then that speculation has become a topic of scholarship in a wide variety of disciplines, including sociology of technology, product and interaction design, literary and art criticism, and postcolonial scholarship, as well as work influenced by these literatures in CSCW.

\subsection{Constructing and contesting future worlds}

Literatures on speculation have articulated (at least) two distinct modes of speculation. One approach to speculation involves creating a specific vision of a sociotechnical future, and orienting action towards making that world come about. While the futures proposed are uncertain, there is a clear path of action that is believed to lead to that future, which its articulation is intended to underwrite. For example, Jasanoff and Kim describe how "sociotechnical imaginaries" - shared visions of a national future that a technology could realize - shape national policies of innovation $[120,121]$. More broadly, STS scholars describe how expectations [38, 128], visions [29, 72, 141], and imaginaries [84, 113, 120,121] about future sociotechnical worlds are constructed within and around technoscientific practice [129].

These futures are performative: i.e., rather than simply predicting what is to come, futureoriented discourses and practices have practical present effects on how technologies develop and how societies make sense of them [129, 152, 154]. Visions of specific futures can be used practically to legitimate planned programs of action by claiming their future value $[113,155]$, to enroll stakeholders into supporting a project $[113,126]$, and to motivate and coordinate actors into a shared program of action [141]. Within CSCW, Steinhardt and Jackson have demonstrated the key role that "anticipation work," or individual and collective orientations to the future, play in collaborative infrastructure development [188]. CSCW researchers have also explored how specific, collective imaginaries of technology shape technology design [68, 144], marketing [189], policy [209], and use [100].

Construction of specific futures, along the lines of this approach, is a self-conscious part of scientific and technical practice [113, 126, 129, 141, 155]. It is common in early phases of many product and interaction design practices, as designers weave familiar imagery with futuristic (i.e. not immediately market-ready) renderings to present a compelling image of what could be. Methods of speculation such as scenarios [42, 98], personas [2], storyboards [197], and prototypes [40] are used to explore and communicate the potential becomings of technology [33], with the goal of shaping the products of tomorrow.

While the work just described primarily leverages futures in order to achieve them, the second approach to speculation develops visions of sociotechnical futures in order to raise critical questions about how futures are established in the first place and to promote viable alternatives. Building on Seefried [182], Konrad et al. describe 'emancipatory' anticipation as "practices that unearth and interrogate metanarratives which buttress dominant visions of technological progress" [129, p. 482]. These approaches ramp up the innovation inherent in speculation into a tool for revolution $[1,111,201]$. Taking, in Womack's words, "imagination as a tool of resistance," [208, p. 24] forms of speculative fiction such as Afrofuturism [17, 37, 61, 77, 114, 158, 159, 208, 215], Chicano futurism 
[177], Indigenous futurism [24, 83, 134], and feminist utopianism [16, 21, 151] explore futures that center protagonists, histories, experiences, and forms of agency elided from mainstream narratives of our technologically mediated future.

Within product and technology design, speculation has been adopted as part of critically-oriented design research that questions conventional technological narratives [18, 66, 74, 80, 103, 123, 169$171,210,212]$, occasionally explicitly evoking speculative fiction $[19,20,59,205,206]$. Speculative design [12] and allied approaches critical design [70] and design fiction [32] are used, among other things, to envision design spaces unconstrained by the practical realities driving many real-world design projects $[36,58,66,73,74,76,95,102,104,124,130,191,193]$ and to critically reflect on the limits of current approaches while suggesting alternatives $[46,51,60,85,122,132,133,168$ $170,200,212,214,216]$. While many forms of design research involve speculation, speculative design in particular suspends the usual expectation that design should meet practical needs in order to engage the reader or user in critical reflection [71, 85]. An explicit goal of speculative design generally, and critically engaged forms of it in particular, is to use design to broaden our imaginations about what is and could be. This may involve educating designers about the implicit assumptions shaping what they believe is possible to design, and then attuning them to new options $[13,32,70,85]$. It can also be directed at a broader public: educating its members on the potential of new technologies and expanding the range of technological possibilities that they could imagine arguing for $[63,67,153]$. Typically speculative design is presented through modernist imagery of polished technological prototypes that while technologically plausible in the near future, evoke a possible but slightly strange social world of use. For example, a designer may evoke an exaggerated version of a social world towards which contemporary technologies seem to be heading, in order to raise questions about the desirability of such a direction.

\subsection{Decolonizing speculation}

The work described so far is largely concerned with speculation in the context of the Global North $[129,175]$. But the Global South has also been the object and site of speculation since at least the 16th century [11,25]. A variety of authors are questioning Eurocentric perspectives of speculation, forming specific answers to postcolonial computing's call to rethink how perspectives from the Global South can inform our understanding of technology and its relation to design $[69,118,165]$.

For example, a lively debate has arisen about the limits of Eurocentric speculative design, particularly around the forms of research related to critical design. An influential line of criticism by Prado and Oliveira [59, 59, 174, 175] argues that speculative design has been almost exclusively caught up in the problems of the intellectual Northern European middle classes. From the authors' perspective, its often dystopic futures largely reflect anxieties of losing first-world privileges, while "your dystopia is happening to us, right now" [175]. Given its aspirations, Prado and Oliveira contend, its narrow topics of interest and forms of representation (often, design prototypes displayed in gallery spaces) render it "curiously apathetic and apolitical" [175].

These critics and others $[8,9,125,195,196]$ have argued that speculative design's forms of imagination are strongly limited by its narrow Eurocentric perspective. They contend that its apparently neutral but totalizing perspective obscures how futures are imagined from, and speak to, particular places $[8,9,125,195]$. Kiem argues that despite its self-consciously revolutionary orientation, speculative design lacks mechanisms to achieve such change and is satisfied to stay in the realm of representation [125]. Tonkinwise sees it as too removed from people's lives, commercial practice, and public discourse to make any material differences [196] and too focused on futures that should not happen rather than on laying out a course towards futures that should happen [195]. Ansari contends that this is particularly an issue in the Global South, where problems are immediate rather than far-off concerns that may or may not come to pass. [9] 
With this spirit in mind, speculative design is being adapted in and to postcolonial contexts. These approaches are often more bottom-up and participatory than the designer-led models often characteristic of speculative and critical design in the West $[173,174]$. They are also more engaged in practical engagement with pressing problems [9], recognizing that there is no safe distance from practical issues to conduct disengaged critical reflection [75]. Researchers are finding opportunities to understand vernacular design in the Global South as a legitimate form of speculation [30, 44-46]. Awareness of the need to think more broadly about where speculative design can come from, who it speaks for, and the perspectives it represents is feeding back into theories of speculative design $[131,211]$.

This critical work in speculative design suggests a need for moving beyond a focus on EuroAmerican actors to think more broadly about who is implicated in speculation and how. One such lens is provided by emerging work looking at how speculation is experienced in the Global South. While the previous work tends to focus on the agency of scientists, technologists, and designers who speculate, this postcolonial scholarship focuses on how financial and technoscientific speculation affect populations who become, in Rajan's words, the "subjects of speculation"[176]: easily accessed and poorly protected targets for Western corporations [164].

But populations in the Global South are not simply the objects or victims of speculation. Speculative projects are also sites for affective investment - places where people seeking a better life entrust their hopes. CSCW has seen a rising interest in how stakeholders in the Global South develop their own visions of postcolonial futures [14, 82, 139, 140]. In postcolonial studies, Cross describes how speculative projects such as special economic zones become sites for a broad range of stakeholders to invest their hopes. They are simultaneously "places in which people attempt to know and master the unknowable future with technologies of planning, calculation, and prediction" [55, p. 424] and "deeply affective spaces in which the future is felt, encountered, and inhabited, in which the lived sensation of future prospects can seize bodies, persons, and selves, gripping them with hope and desire, anxiety and fear" [55, p. 425]. The ambivalence of this reaction is a reasonable response to the uncertainties of postcolonial development, where infrastructural projects are promised but may never come [43], but nevertheless provide a foothold for gathering concerns and dreams about one's community, its practices, its future, and the role of the state in assuring these [97].

As states in the Global South actively enroll citizens into speculation in order to satisfy their desires for a better future, this enrollment can become a double-edged sword. For example, Lord describes how local Nepalis are offered the chance to invest in a local infrastructural development project in order to reduce community opposition. While this allows people to be authors rather than targets of development, it also requires them to bear the burden of the risks it creates [142]. Closer to $\mathrm{CSCW}$, Irani describes how speculation in the form of entrepreneurial innovation is becoming a dominant framing for addressing social problems in India. While this harnesses citizen energies and gives a sense of agency, it marginalizes other forms of social organizing that could provide redress [117]. Avle et al. describe how, as entrepreneurial approaches from the Global North are creatively adapted in Global South contexts, this usage simultaneously reinforces the cultural authority of those apparently universal methods [15]. And kaiying et al. describe how an artist collective's efforts to craft a uniquely Indonesian culture of making is simultaneously celebrated and co-opted by better-resourced foreign institutions [139].

\section{OUR APPROACH}

To summarize, we have identified two significant strands of speculation in social science and design research centered on the Global North: one focused on constructing paths towards specific imagined sociotechnical futures, the other contesting dominant narratives of the future. When viewed from 
the Global South, however, even the critical traditions within technology design can seem hemmed in - unexpectedly conservative. In and out of CSCW, when viewed from the ground in the Global South, speculation becomes a complex and fraught space. In the charged and unequal spaces of development, speculation simultaneously spins off hope and danger, desire and fear, agency and exploitation. Across this variety of literatures, researchers identify mechanisms, practices, tactics, and motivations for speculation in technoscientific development. This literature also suggests that these mechanisms, practices, tactics, and motivations likely play out differently in spaces that are not at the imagined centers of technoscientific development.

Our goal is to build on these insights to better understand how speculation works in unequal spaces on the global periphery. We do so by exploring two historical case studies of state-sponsored projects that leveraged sociotechnical imaginaries of modern futures as developed states. Both case studies involve recent British ex-colonies trying to move up the economic chain by shifting from primary production to production of goods and services. The first involves development projects in the 1950s-1960s that attempted to transform the new Canadian province of Newfoundland and Labrador from its self-understanding as an impoverished backwater to a thriving, modern economic center. The second begins in Jamaica in the 1970s and involves a series of national development efforts to spur the country to developed nation status through tactical alliances with foreign investment.

Previous work differentiates between Global North and Global South. To explore issues of structural inequality, we deliberately juxtapose two cases across the Global North/South divide. These states are nevertheless in a similar structural situation: remnants of the same colonial empire, historical trading partners, and self-understood underdeveloped states seeking to achieve developed status $[4,149] .{ }^{1}$ Framing these cases as developing vs. developed would imply a historical trajectory of progress towards development that these cases will call into question. Instead, we frame our cases within the sociological center-periphery model [184]. This model differentiates centers, as places with high levels of capital and wages and strong formal economies, from a periphery with low capital and wages and a more informal economy often based in subsistence production. This model sees centers as structurally using their powers to extract economic surpluses from the periphery, e.g. by outsourcing labor to lower-wage regions. It thus calls attention to the power imbalances at the core of our concerns.

There are many ways that speculation is leveraged across contemporary society. For the purposes of these case studies, we focus on a specific form, which builds on CSCW work on speculation, STS work on technoscience, and design research: practices that articulate, and aim to build towards, a specific, collective, possible but uncertain future. This definition highlights three aspects: (1) vision: the construction of a specific, imagined, sociotechnical future, (2) actions: actions in the present which are justified by working toward that future, and (3) possibility, i.e. a sense that the futures involved are risky, experimental, unproven, or uncertain.

'Risk' with relation to modern societies is often understood in terms of statistical risk, involving ways to convert danger into calculable categories manageable through actuarial techniques [1, 86, 143]. But our focus here is not on financial speculation. We use the term 'risky' more generally to highlight what is at stake in the uncertainty of speculation, what one of our actors will term 'make or break:' taking a long shot, hoping things will work out, while recognizing that if it does not, the consequences will be serious.

In our approach, we integrate design, social science, and historical perspectives from the literature. Design perspectives highlight choices made by actors in our cases to frame futures and to shape

\footnotetext{
${ }^{1}$ Newfoundland and Labrador's underdevelopment coexists with a colonizer relationship to its own Indigenous population, a situation Vodden terms 'nested peripheries' [202]; this population was largely ignored in the projects we will describe.
}

Proc. ACM Hum.-Comput. Interact., Vol. 5, No. CSCW1, Article 121. Publication date: April 2021. 
actions towards them. They give us a language for identifying and evaluating trade-offs in strategies and tactics used. Social science perspectives help us look at how these actions are understood by a broader set of actors and interact with ongoing social dynamics. By taking a historical perspective, we are expanding the reference points of design research to consider how its tactics relate to those explored at other times, in other places, and by other actors. This historical perspective also enables us to consider the long-term workings of speculation on the periphery over the course of decades. This work is inspired by and builds on work in HCI and CSCW that advocates for a greater engagement with history in technology design [5, 7, 28, 34, 35, 65, 89-94, 179, 194, 210, 214].

We use these cases to explore how the unequal political playing field and the race to 'catch up' with other nations interplay with narratives of technological progress. In the following cases, we trace how this context shapes the speculative strategies chosen by national governments, how those speculative practices intersect with the reality of deeply pressing problems on the ground, and the outcomes of these strategies and practices. In a combined discussion section that follows the case studies, we describe key tensions in these cases, and use them to characterize how speculation works from the periphery.

\section{INDUSTRIALIZING NEWFOUNDLAND}

Newfoundland and Labrador is a Canadian province whose economy was historically based in the small-boat fishery. Never prosperous, the independent nation of Newfoundland went bankrupt during the Great Depression and returned to British colonial rule. A damning report concluded that Newfoundlanders were to blame for their own poverty [48]: Newfoundland was considered a failed colony, its white colonizers having reduced themselves to the status of the colonized [56]. In 1949, Newfoundland became the Canadian province of Newfoundland and Labrador. Its new premier, Joey Smallwood, faced a huge challenge. He had promised to improve the lot of the "little man" [96], understood as struggling rural whites - a problem that had bedeviled prior governments. He faced new dangers as the economy of Newfoundland and Labrador was integrated with a more powerful and prosperous Canada. There were no more tariff barriers to protect Newfoundland industries from Canadian competition, and immigration barriers to stop its residents from leaving en masse to seek a better life on the mainland [135, p. 7]. Next, we characterize the speculative vision Smallwood developed to counter these problems. We then detail the speculative strategies used to turn that vision into action in two specific projects, and describe their outcomes.

\subsection{The vision of industrialization}

Newfoundland and Labrador's problems were common for ex-colonies: a faltering economy based on natural resource extraction [4]. Poverty, malnutrition, and high child mortality rates were endemic to the villages where many residents lived. At this time, international consensus saw industrialization as the path to prosperity for underdeveloped regions [22, 213]. Smallwood believed the province must industrialize as rapidly as possible. He saw the traditional fishing villages, or 'outports,' that then characterized Newfoundland and Labrador as hopelessly out of date. $\mathrm{He}$ articulated a vision of a transformed province, with new industrial centers replacing outports, steady-wage factory jobs replacing the independent fishery, and Newfoundlanders transformed from rural peasants to consumers enjoying modern amenities. "Burn your boats!" Smallwood is said to have exclaimed. "There'll be two jobs for every man!" [147, p. 40]

This vision resonated with outport residents. The Depression years had been miserable. During World War II, outporters flocked to employment on Canadian and American military bases; exposure to North American standards of living raised new dissatisfaction with outport life $[22,112]$. They began to understand themselves as stuck in the past compared to their North American neighbors [22, p. 97] [53]. Smallwood presented an optimistic view to solve the province's problems that 
communicated respect for the potential of its citizens, in contrast to the colonial government's blame of Newfoundlanders for their troubles.

To imagine Newfoundland and Labrador at that point as potentially industrializable was audacious, for opposition politicians even laughable [39, p. 133]. Much of the population lived in small villages reachable only by sea and subject to harsh weather conditions. The province was rich in some natural resources, but other goods had to be shipped in and out at high expense. Electrical power was rare. While Labrador had waterfalls suitable for large-scale electrical production, the island of Newfoundland would likely be dependent for power on expensive imported fuels. Newfoundland and Labrador lacked local labor trained to run factories or work in them [135, p. 35]. There were few local industries, and many of those went out of business on joining Canada because they could not compete with mainland manufacturers working at scale [22, p. 98].

But Smallwood believed that there was little choice; Newfoundland and Labrador must, in his words, "develop or perish" [135, p. 7]. The only way forward was to industrialize as quickly as possible, building factories and creating jobs before the population moved away $[22,135]$. To do so would, in Smallwood's view, require attracting expertise and capital from outside the province. And this was no easy task, since there were many more obvious places in which to invest. Smallwood saw the circumstances as so dire that they necessitated taking risks: "People are not going to wait forever for this development; if we don't give it to them tomorrow, they get more and more out of jobs and pull up their stakes; ... Our job is to back them; go right out, boots and all, make or break. Here, what I mean by 'make or break', here is gamble" [22, p. 104].

This speculative vision of development was instantiated through numerous modernization programs $[49,162,213]$. Here, we focus on two programs key to Smallwood's legacy: one aimed to eradicate aspects of provincial culture considered incompatible with an industrialized future, the other aimed to jumpstart that future as quickly as possible.

\subsection{Resettlement}

The first approach the Smallwood government took towards this future vision was to restructure present provincial society to meet it. Under Smallwood, there was a growing sense that small outports were incompatible with modern society. Industrialization was thought to require a large, mobile pool of labour [49]. It was also hard to imagine how to provide modern services - electricity, telephone, medical care, education - in scattered settlements [110]. Government planners began to believe outporters should resettle from fishing villages to larger centers where they could access centrally supplied services and engage in factory labor $[49,204]$.

This program started modestly, in response to individual petitions arriving from outports asking for financial help to move to larger towns. It was soon expanded and modified to more systematically encourage resettlement, e.g. by requiring entire communities to resettle and prohibiting people from moving back to their original communities [167]. The province began analyzing communities' perceived economic potential to decide which should be 'growth centres' and which communities should be encouraged to migrate, decisions reached in secret [204]. In 1965, financial incentives to move were significantly increased, and thresholds for community consensus about resettlement were dropped from $100 \%$ to $80 \%$ of households being willing to move [145, pp. 4-5].

Step by rational step, the government moved down a slippery slope from supporting to coercing resettlement. Resettlement now pitted neighbor against neighbor: those who wanted to move against those who wanted to stay [148, p. 2442]. Ostensibly residents were free to stay, but when $80 \%$ resettled, the few services had by the $20 \%$ who stayed behind in a gutted community were eliminated as well [145, p. 5]. When the government decided a community should be resettled, it often stopped maintaining or extending infrastructure such as post offices or wharves because that 
seemed wasteful when the community would anyway soon cease to exist [185, p 280]. Such actions led to rumour-mongering and fear in potentially targeted communities.

From 1954-1975, around 250 communities with 27,500 total residents were resettled [145]. This was a benefit to some: when life became so difficult that a household wanted to emigrate but could not, financial support made it possible to start a new life elsewhere [31,50]. But other resettlers found that moving traded one set of problems for another. The factory jobs promised in larger centers rarely materialized $[110,145]$. Without access to traditional subsistence resources such as fish, lumber, and fields, people who had rarely seen cash now desperately needed it [110].

When it began, resettlement was seen as a visionary approach to dire problems in rural communities (e.g. [199]). But the more the program was rationalized, the more problematic it became. As communities felt under increasing pressure to move and the scope of changes taking place became clear, opposition began to mount [148, p. 2442]. Focused on immediate practical benefits, planners had not calculated in the emotional toll of uprooting deeply settled communities [31]. Like other development projects at the time [181], the resettlement program's rational implementation of a state-sponsored speculative vision led to violent consequences [31, p. 242]. Today, "[w]hat tends to be remembered are divisions within families and communities, social dislocation, the loss of a way of life, and the abandonment of communities which, in some cases, had existed since the early days of European settlement" [108]. While in retrospect some view the program positively, many see it as a short-sighted abandonment of a central part of provincial culture to an industrial development model ill-suited to the province [146, 148, 185].

\subsection{New Industries}

While resettlement focused on altering the historic conditions of society in the province to prepare for a hoped-for future, the new industries program aimed to quickly make that future a present reality. This program, launched in the early 1950's, aimed to use startup capital received from Canada on Confederation to jumpstart industrialization by stimulating factory construction.

The government began by directly funding 3 new industries, then looked for investors to generate more. Smallwood had trouble finding them locally; provincial residents had little capital, while Canadian, British, and American investors saw Newfoundland and Labrador as too risky for investment [135, p. 16]. Smallwood decided the circumstances required more desperate measures. "Since he could not 'grab a man by the throat and compel him to invest his capital and start a new industry,' Smallwood was beginning to ponder different avenues. Temperament, conviction and circumstance compelled him to consider taking greater risks" [22, p. 104]. He took advantage of post-World-War-II chaos in Europe to attract investors and business experts from Germany and what was now the Eastern bloc, by offering them the opportunity to emigrate to Canada through Newfoundland and Labrador, a strategy Smallwood termed "fishing in troubled waters" [22, p. 113]. Through this route he recruited a Director General of Economic Development, Alfred Valdmanis [22, p. 110], who had led Latvia's successful industrialization project [22, p. 106].

Letto [135] provides a detailed analysis of the industrialization program. The government put together generous financial packages to attract capital, which often involved the province taking on much of the financial risk of the factory project and requiring little in outside or long-term capital investment [135, p. 2]. Soon, amid much fanfare, a series of factories were built, intended to produce products such as shoes, knitwear, and chocolate [135, pp. 31-32]. Factory projects were proposed and approved at breakneck speed, apparently requiring little vetting [135, p. 27], [23, p. 250]. As Valdmanis himself put it, "I was no civil servant. There were no rules, no regulations, no contracts. I had to make a fast start” [23, p. 250].

The lack of vetting led to immediate problems with the factories. For example, a cement plant had massive cost overruns [135, p. 24]. One hardwoods plant was subject to a government investigation, 
a strike and replacement of its technical manager in its first year; the second had problems with materials it was too short of capital to fix [135, pp. 26-27]. A rubber plant "lurched from crisis to crisis" [135, p. 31]. The optimistic estimates of factory employment motivating government investments rarely played out; a battery plant promising 100 jobs employed 17 after 2 years [135, p. 30], a tannery promising 200 jobs employed 21 after 4 years [135, p. 28], a textiles plant promising 800 jobs employed 100 after 6 years [135, p. 29]. While the government knew about the deep problems the factories were facing, publicly Smallwood continued to produce glowing reports of the success of the new industries [135, p. 34]. To do otherwise would have undermined his core strategy to create an imagined industrial future: convincing Newfoundlanders and outside investors it was realistic enough to be worth investing in.

By the mid-1950's, however, problems were increasingly obvious, as the high costs of shipping and the low availability of skilled labor took their toll [135, p. 35]. One by one, factories the government established were rejected by potential investors as subpar and unprofitable, while factories started by investors went out of business [135]. "[N]o level of optimism could counter the disastrous results that started showing on the balance sheets of most of the companies" [135, p. 42]. In the end, after a CAD $\$ 26$ million public investment, only 4 of the 15 factories remained in business, employing a few hundred people [135, p. 64]. Smallwood's minister for development, Valdmanis, went to prison for accepting kickbacks from plant builders [109]. The new industries program started with a spectacular vision and ended as a spectacular disaster.

Smallwood's strength as a leader was his ability to articulate a compelling vision of the future that gave many residents hope and enrolled them into building towards that future. We described two projects for achieving that vision; one attempted to eradicate aspects of Newfoundland and Labrador society seen as incompatible with it, the other attempted to quickly bring that vision into reality. The first program largely accomplished its goal; the second did not. This left an awkward situation where prior economic coping strategies had been rendered impossible while promised new ones were largely unavailable, a situation that arguably continues to hold in rural Newfoundland and Labrador today [161]. Letto argues that while the province's citizens may believe they were uniquely gullible to believe in Smallwood [135, p. 65], such costly, uncertain, and ultimately unsuccessful attempts to address underdevelopment are common in smaller states - as we will see next.

\section{CREATING FUTURE JAMAICAN INDUSTRIES}

The Newfoundland and Labrador case involved a desired shift from a subsistence economy on the periphery to economic models modeled by the center. A compelling vision of this future was used to enroll citizens and other stakeholders in state plans. Precious resources were invested in programs of action to instantiate that vision, which failed spectacularly and at a high cost. Unfortunately, we will also see these attributes at play in Jamaica. But this case will also highlight speculation as an ongoing, contingent activity rather than a one time work of fiction. To have any chance at success, planners had to situate their visions within a long-running internal conversation about the country's future. And the producers of these visions, as well as the leaders of the efforts to realize them, had to maneuver within shifting constraints overdetermined by present realities created and future trajectories proposed by international agents.

Like Newfoundland and Labrador, Jamaica's forms of speculation have their historical roots in their role in the British empire. The British captured Jamaica from the Spanish in the 1650s as part of their empire's broader build up of power across the Caribbean. The island became a significant source of the empire's wealth via the slave trade and the agriculture those bodies fueled. The intensive production of sugar through slave labor shaped the social and economic trajectories of the island and also the larger global economic frame within which the island could stake out a future for itself. So while slavery was abolished on the island in the 1830s, and a nationalist movement

Proc. ACM Hum.-Comput. Interact., Vol. 5, No. CSCW1, Article 121. Publication date: April 2021. 
eventually secured self-governance in 1962, neither form of formal independence brought significant economic self-determination.

Jamaica's leaders have since struggled to build a strong, independent economy outside of the colonial relationship in which it had functioned for hundreds of years. The British had left behind intentionally uneven industrial development along with significant socioeconomic and racial inequities $[78,150]$. Across decades, Jamaican leaders set out an array of development projects, which featured a range of possible future Jamaican societies. These featured vastly different models of economic and social engagements with a world beyond the colonial metropole, and different versions of a Jamaican citizenry best suited for them.

In this section, we discuss two of those projects. They demonstrate how national leaders across differences in scale and political orientation used speculative practices and fantastic imaginaries to encourage present action by their citizens and the outside world. In both projects, planners ground their speculations in the possible by referencing or repurposing key moments in national history or by tapping into the country's accumulated cultural capital. As in Newfoundland and Labrador, they also used the fantastical and the fictional to provide their imagined futures with the lift necessary to generate effective and affective engagements with other nations, international corporations, and their own citizens.

In the first case, leaders charted a path for the island that emphasized resistance to imperialism and the extremes of capitalism, and promoted the possibility - if not the inevitability - of harmonious conjunction with other nations outside the binaries of West or East. The second case corrected the first, after ambitious plans for a planned economy and self-sufficiency failed to find a stable foothold. This future Jamaica featured an economy growing in tandem with the US, with citizens who have "upskilled" and are newly relevant for keeping the nation ahead in a digital world.

\section{1 "Better Must Come"}

The first set of speculative projects were a reaction to the dominant modes of development in the prior decades after WWII. As was common under colonial rule, Jamaica's role was to be a peripheral supplier of raw materials as inputs to industrial engines at the center [78]. The country's early nationalist leaders sought to change this narrative through an "industrialization by invitation" strategy [138]: they provided incentives such as tax breaks, tariff protections, and subsidized factory spaces to foreign corporations, in an attempt to transition from its agricultural base to one that relied on manufacturing, mining, and tourism [150]. But popular consensus was that the resulting prosperity had not been distributed to the island's lower classes [47, 136]. A decade after independence the Jamaican economy was still dominated by a sliver of the population and divided by stark racial lines.

The ascendancy of Black power movements like the Universal Negro Improvement Association (UNIA) had animated personal and national visions. A sense of possibility rested on Jamaica's significant bauxite reserves, combined with the commodity boom of the 1960s and 1970s which had given many Third World countries the hope that they could turn trade to their advantage and thus find economic reliance $[6,136,190]$. A growing movement across the Third World appeared to be mobilizing alternatives to alignments with Western market capitalism.

In 1972, the People's National Party (PNP) presented a vision of redress and redistribution in their election campaign against the Jamaica Labour Party (JLP), who had been in power since independence. Their campaign slogan, "Better Must Come," was pitched to the largely Black lower classes who had not benefited from the previous decades of foreign-led industrialisation. The PNP won, and once in power, set about implementing and then expanding their vision for Jamaica. In the years that followed election, Michael Manley, the leader of the PNP and the country's Prime Minister, argued that the Jamaican experience demonstrated that "capitalist strategies of political 
and economic management cannot solve the basic problems of our people" [27, 24]. The country's new leaders increased tariffs on the export of bauxite, nationalized key industries, and improved worker's rights and wages.

Manley placed the Jamaican people's struggle within the broader context of Third World concerns during the Cold War and a fight against imperialism and capitalism. He called for greater coordination and cooperation among the primary producer nations that produced raw materials for industrialization but did not benefit in proportion. He called for greater transparency and accountability between international financial institutions like the IMF and the Global South. And, he called for new south-to-south financial clusters, all grouped under his vision to "share the wealth...[not]...spread the poverty" $[166,188]$.

Manley imagined a future for Jamaica outside of what he saw as a pattern of exploitation in the region. Here, America was a symbol of the West and was responsible for continually reproducing the unjust world order of the colonial era. Speaking at a conference for non-aligned countries held in Cuba in 1979, Manley noted that while the leaders of developed countries were increasingly adopting the "rhetoric of progress" and denouncing apartheid, none were taking significant action against transnational corporations who operated there. "Clearly" then, Manley continued, "the struggle is against unjust trade relations; unbridled, transnational corporate power; or any of the other elements of the unjust system of world economic exchange" [198, 336-337]. For Manley, this required that Third World countries develop self-reliant programs amongst themselves and thus "change the equation of economic power".

But while the first years of the PNP administration were marked by the country's highest standard of living, this prosperity was short-lived [137]. Manley's close relationship with Fidel Castro and Cuba created tensions both at home and with the United States [6, 190]. The oil price shocks of the early 1970s drastically raised the cost of imports, the global recession of the 1970 s engulfed the island as it did much of the then Third World [190], and the global demand for bauxite plateaued while tourism contracted, choking the economic engine that supported the execution of the party's vision. With no turnaround in sight, the nation began its first borrowing agreement with the International Monetary Fund (IMF) in 1978, requiring difficult economic adjustments that included liberalization of trade, privatization of the economy, and austerity-oriented measures such as cuts to social spending and other welfare reforms [105, 106, 137, 203].

\section{2 "Deliverance is Near"}

The second set of speculative projects arose in response to the perceived limitations of the first. In the 1980 general election, the JLP won a violently contested referendum on two visions of Jamaican society and the island's position within a broader East-West tension. Campaigning under the slogan "Deliverance is Near", they promised Jamaicans an alternative to the preceding economic failures under the PNP. This vision was addressed both to the working class on the island struggling with food shortages and the effects of austerity, and to the mercantile class that had fled the country in the previous decade fearing the trajectory of socialism.

This new idea for what Jamaica's economy and people should become was in tandem with the 'Reaganomics' of the nearby US and the ascendancy of market-oriented politics $[99,127,178]$. Edward Seaga, the newly installed Prime Minister, would be the first foreign head of state that the US president received after taking office just a few months later; Reagan himself declared, "Jamaica is making freedom work" [178]. In this joint vision for the island, Jamaica would become an exemplar for free-market democracy principles centered around the US, growing as the US would. Instead of proposing that Jamaica follow a different mode of development than the West, this vision proposed that Jamaica's success would be found within it. 
This new story was a reversal of the last. A key component was encouraging economic liberalization and direct foreign investment through the promotion of Free Trade or Special Economic Zones: areas of the country in which foreign companies could operate while receiving incentives and reducing taxes. While these underregulated areas had existed before, they found a speculative apex when remade as sites for informatics work and a larger Business Process Outsourcing (BPO) industry. At the time, companies in the US were increasingly externalizing their "back office" services following advances in "electronification" technologies [107]. Jamaican planners envisioned a mutual benefit: their trainable, English-speaking populace, combined with the region's geographical and cultural proximity to the United States, would allow a local "nearshoring" industry to grow alongside the efficiency demands of American businesses. This would simultaneously achieve America's goals for informatization and Jamaica's for national development $[172,180]$. Multi-national firms would employ and "upskill" citizens, facilitating technology transfers that would enable a local software development and services industry [116].

This vision was directed at potential companies and investors. Marketing materials depicted state dreams not yet realized: neoliberal tropical paradises with open economies and friendly natives [88, 116, 127]. It was also directed at workers; both government promoters and business managers accentuated the symbolic links between computers and white collar respectability. The allure of "new" technology presented a new speculative arena for creating and manipulating worker's identities [81, 157]. The workers - largely women - were encouraged to see themselves as white-collar employees, with the clothing to match, in the hope that this would circumvent the development of a "militancy characteristic of organised industrial workers" [163, p. 61].

However, decades later, BPO, while a significant source of employment, has not delivered largescale transformations "up the skill ladder" $[115,193]$ for the nation or for workers [52]. In part, this utopian data vision remained unrealized because hoped-for technology transfers failed to materialize. In reality, most foreign firms only offered basic data entry and call-center services, while much of the high-value services such as software development remained within the US. And lower-priced competitors have emerged, spread across the globe but now readily accessible following continuations in the improvements to the telecommunication networks that initially made Jamaica a viable site [156]. While corporations have poured raw data into Jamaica, they have not been keen to distribute the wealth and expertise that emerged from processing it.

\section{DISCUSSION: SPECULATION FROM THE PERIPHERY}

Both cases involve states on the periphery crafting specific imagined futures in which they have arrived as developed economies. These imagined futures were deeply informed by events in developed centers. Newfoundland and Labrador aimed to catch up with the rest of Canada, while Jamaica first plotted an independent economic trajectory that countered visions from a First World center, then sought to become indispensable to it. These imagined futures were used to underwrite concrete programs of action that enrolled citizens and other actors in national development projects. While both states poured enormous efforts into these projects, until now they have failed to establish their hoped-for futures.

Each case's approach to speculation was shaped in some ways by its unique cultural and historical situation. Newfoundland and Labrador's approach to development was shaped by its self-understood whiteness. While the colony of Newfoundland participated in imperial slavery by supplying salt cod as cheap protein for slaves in the West Indies, Newfoundland was itself colonized without significant slavery. With its native population first decimated and then invisibilized, Newfoundland's impoverished settlers became a main source of cheap labor, considered the sign of a 'failed' colony $[48,57]$. On Confederation with Canada, Newfoundland and Labrador engaged in a desperate race to 'catch up,' to become like nearby white-dominated settler states. Its speculative strategy 
was to adopt directly forms of industrialization that had already succeeded in Canada and the US, irrespective of whether they suited the local context.

This strategy contrasts with successive Jamaican governments' embrace of alternative paths to development tailored to its geographic, historic, and cultural situation. Jamaica is a Black nation, born through slave labor, but with a history as a keystone of the British empire, and with outsized cultural influence. In 1970s Jamaica, a century of travel around the commonwealth, combined with the narratives from Black power movements, had animated personal and national visions of untapped power that rendered bold alternative futures plausible [41,101,187, 192]. But through the 1980 s and beyond, as Jamaican national debt mounted, anticipated futures became less ambitious yet more unlikely, building on successive hopes that this time the tactic of becoming indispensable to the centers of capital would work out $[127,183]$.

Speculation in both cases, while audacious, was tied to pressing problems that urgently needed resolutions. In their marriage of audacity and necessity, these cases embody a mixture of stances that can appear incongruous. As we will describe below, research on speculation has identified core tensions within it between fantastical speculation and pragmatic problem-solving $[79,171,196]$; between reality and fiction $[32,188]$; between attention to pasts and to futures $[64,113,155,174]$; and between conservative and emancipatory orientations [129]. We see these very tensions arising empirically in these projects as they appear, from moment to moment, in turn fictional and realitybased, highly pragmatic and wildly fantastical, emancipatory and conservative, focused on the future and wrapped up in the past.

Our core argument is that these incongruities come about because these projects on the periphery were working together two different modes of speculation. The first mode is constructive, as in normative technoscience, aiming to establish state and corporate futures. The second mode is contesting, as in speculative design, and questions received futures. In the constructive mode, these projects aimed to create a coherent vision of a future societal situation that could motivate and underwrite action in the present. That action would establish the projected future by providing a sense of certainty within the very real challenge of creating economic prosperity for smaller postcolonial states painfully aware of their marginal roles on the world stage. In the contesting mode, these projects envisioned alternatives to a status quo which would leave them stuck in 'developing' status. These visions of themselves as established economic powers, or even as states with full agency, questioned established realities and power structures.

Speculation from the periphery, we argue, necessarily tacks between these constructive and contesting orientations. The ambivalence in these cases arises from clashes that arise when those perspectives are worked together in practice. Here, we describe how the previously described tensions of speculation are reworked in these cases, leading to 4 key consequences: (1) fantasy and pragmatic goals become deeply yoked; (2) the center's reality becomes the periphery's fiction; (3) speculation about the future is intertwined with speculation about the past; and (4) asserting the center's status quo becomes an emancipatory act.

\subsection{The fantastic as pragmatic}

In speculative design, speculation is often considered different from, and sometimes opposed to, direct, instrumental problem-solving $[79,171,196]$. The choice of speculating is often framed explicitly as unconcerned with solving the practical problems of the present in order to offer alternative viewpoints on what the future could hold $[76,85,104,193]$. This orientation underwrites the formulation of more audacious, less probable futures. On the surface, these cases seem instead to follow what we have described as the constructive path of technoscience. Instead of separating speculation from the mundane, practical realities of everyday life and its problems, actors in these states used speculation as a means to address them. Yet in Newfoundland and Labrador, the futures 
imagined were so speculative as to seem fictional, even to contemporaries. Given the enormous practical problems Newfoundland and Labrador faced, why did state actors try to solve them with speculative visions that seemed so improbable? One reason they built on an unlikely future was because they had little choice. In postcolonial Newfoundland and Labrador there was no clear route to a prosperous future, aside from outmigration. Unlikely futures were the only way forward, and this licensed possibilities that otherwise would seem impossible. As Simone writes about contemporary Kinshasa, when there are no viable futures that institutions can underwrite, "everyday life becomes intensely experimental" [186, p. 122]. Such speculation is rooted in "a freedom not won by virtue of some alternative path or ability to be impervious to the predominant forms of rule. Rather, it is a space opened up by virtue of turning uncertainty into a resource" [186, p. 123]. A similar dynamic characterizes Jamaican speculation; when ambitious but plausible futures were derailed and as mounting national debt reduced the room to maneuver, planners shifted to ever more unlikely imaginings of a road to upskilled prosperity through attracting offshore capital.

In speculative design, speculation is explicitly used to break out of the limits placed by pragmatic concerns. When speculation is understood as necessary for survival, however, the line between what is speculative and what is practical becomes difficult to discern. In our cases, speculation was leveraged to fulfill pragmatic roles. Most crucially, it enrolled a wide array of actors into otherwise difficult or impossible future-making exercises. In both states, their largest exports were their people [87, 160]. Their speculative fictions harnessed affect to help citizens see themselves as part of their state's future story. In Newfoundland and Labrador, this work staved off a flux of outmigration and emigration to other parts of North America and enrolled citizens to work towards these futures in the periphery rather than leaving for better economic prospects in the center. In Jamaica, where identity and location are diasporic in character, efforts in the 1970s not only unified Jamaicans abroad with those at home, but also enrolled a larger Pan-African diaspora in a common project of liberation. In both states, efforts enrolled external economic actors - refugee East Bloc investors, multinational firms, Jamaican expatriates - to invest in local economic activities.

Enrolling affect is a typical role for speculation, whether as a part of technoscientific programs $[113,121,141,155]$, development projects [97, 142], or design [62, 70]. On the periphery, these questions of affect become particularly urgent, because they are tied to the desperate conditions that speculation is intended to address. Smallwood, for one, had an urgent problem to address: the expected outmigration of a large portion of his province's population on Confederation with Canada. "Every opportunity was seized to dispel apprehensions 'that the future here was dull or uninspiring, or that this was a place to leave, or that this was a sinking ship"' [22, p. 104]. When speculation proceeds from such desperation, arguably the ambition of the vision must appear in proportion to the scale of the felt problem that it addresses. The very desperateness of the practical situation requires a truly fantastical vision to counterbalance its affective pull.

\subsection{Reality as fictional}

In these cases, we also see a striking intertwining of fiction and reality. Not-yet-existing, possiblyfictional futures motivate real, existing programs of action that are intended to actualize them. This may in fact be true for all design projects that aspire to create change in the world [141, 188], but the landscape shifts when the gap between those imaginaries and the dire economic straits they were intended to practically address becomes profound. Speculative design similarly widens the fictional gap between present reality and future circumstance, but this is done to generate dissonance that undercuts the inevitability of those futures. A similar dissonance is unintentionally produced by the gap between vision and reality in these development cases.

State actors in these cases, then, faced a tactical dilemma. In Newfoundland and Labrador, state actors needed to generate enough affective investment to counteract an overwhelming impulse to 
migrate. Jamaica needed to generate a vision large enough to generate common bonds across the seemingly intractable socioeconomic differences of its citizenry: the bigger the vision, the more likely everyone could eat. They had to think big. But the bigger the vision, the more far-fetched it would seem, particularly in contrast with pressing problems on the ground. How did they create a reality effect around these visions to make them seem plausible?

One answer is suggested by Beckert's analysis of the role of speculation in economic decisionmaking [26]. Beckert argues that it is a mistake to see fiction and reality as in conflict. Instead, they are intertwined. Fiction is defined, not by its counterfactuality, but by the creation of its own world, a reality one can experience in imagination. Fictions are necessary in economic decision-making because the future is uncertain; they represent the future as if it were true so that actors can act today with reference to an otherwise uncertain future. What makes a fiction 'realistic', then, is not whether it is true but whether it can create a sense that it could become true. In particular, Beckert argues, fiction becomes credible when it is coherent and embeds references to the non-fictional.

In our cases, the fictions driving economic decision-making draw on clear references to neighboring states as specific coherent, non-fictional realities. In Newfoundland and Labrador, the power of images of an industrial future were fed by its citizens' growing awareness of North American standards of living and their comparative poverty. Confederation with Canada created expectations of similar standards in their own future. Crocker argues that in Newfoundland and Labrador, as in other postcolonial spaces, " $[\mathrm{t}]$ he future was not an unknown space of experience; it was visible elsewhere" [53, p. 83].

Jamaica at first rejected this idea of copying the center's realities to instead create an ambitious but plausible future in collaboration with its peripheral neighbors. But when these plans became untenable and imagined futures more improbable, it grounded those less likely visions in an industrial trajectory that built on the capitalist expansions of the nearby United States and its imaginations about the role peripheral locations would play in them. In both Newfoundland and Labrador and in post-1970s Jamaica, then, state actors established legitimacy for audacious visions in the face of dire straits by linking realities elsewhere to fictions at home. The center's reality in these cases motivated and underwrote the periphery's aspirational fiction.

\subsection{Envisioning the future by envisioning the past}

The manner in which the center's present reality became worked into the periphery's future unsettles the assumed orientation to past, present, and future that often underlie strategies of speculation at the center. Typically speculation is framed as a future-oriented enterprise, such as when Dunne and Raby introduce speculative design as oriented around envisioning possible futures [71, pp. 2-6], or Jasanoff and Kim describe sociotechnical imaginaries as inherently futuristic [120, p. 123]. But despite the emphasis on futuring in speculation, orientations to the past are also implicitly present. Speculative design, for example, references contemporary styles in its future imaginings [64], while sociotechnical visions of the future ground their plausibility in past collective experiences of technology that shape what can seem possible [113, 155]. But, Prado and Oliveira argue, while speculation always incorporates references to the past and present, its historical narratives in the West orient around a linear progression from past to present to future, referencing the fundamental progress narrative around which technoscience is commonly organized [174].

Speculation in our cases is similarly oriented towards breaking from the past to establish a more promising future. In Newfoundland this involved shifting from primary production to industrialization. In Jamaica in the '80s and '90s, it involved leaving the heat of the plantation and the manufactory behind for the cool, temperate work of informatics. On the surface these seem like standard progress narratives. But, Oliveira and Prado argue, linear progress narratives quickly go wrong in the Global South, whose people are understood as "constantly trying to catch up with

Proc. ACM Hum.-Comput. Interact., Vol. 5, No. CSCW1, Article 121. Publication date: April 2021. 
time, but inevitably fall[ing] back" [59]. In writing about time sense in Newfoundland and Labrador, Crocker, drawing on Appadurai [10], describes how the reliance on the central present to shape peripheral futures creates "a new colonial sense of progress as repetition.... of a process that has already taken place elsewhere" [53, pp. 85-86]. This shift from linear to repetitive understandings of progress leads to an odd splitting of experienced global time, in which some localities are apparently 'in the present' while others are simultaneously 'in the past' [53, pp. 85]. The compelling desire to join the present elsewhere creates unsettling temporal effects on the periphery. "Backward peoples skip stages and jump historical intervals in order, as Trotsky once said, 'to adopt whatever is ready in advance of the specified date' " [53, pp. 86].

With their temporal ordering unsettled in these ways, states in our cases of speculation on the periphery not only speculate about the future, but also about the past. Planners posit a future to which citizens can aspire, or that delineate what the province or nation hopes to become. At the same time, these visions are clearly framed against ideas about the past, what is worth retaining, and what should be abandoned.

At their best, such strategies rejigger imposed historical narratives to tell new stories of the past and its potential legacies for the future. Aspects of this past can then be called on as key elements of national identity to be preserved or built on for the future, such as Jamaica's rich history as a vital node in the network of global trade. Oliveira and Prado go further, arguing for a strategy of deliberate anachronism in speculation in the Global South to break the hold of linear progress narratives [174]. For example, they present newly designed prototypes not in imagined futures but in past political and cultural contexts such as the Latin American military dictatorships of the 1970s. These strategies are intended to break the temporal stranglehold in which far-away futures are valorized over the continually recurring past.

At other times, however, these strategies result in an internal repetition of the external temporal sort that places peripheries in a less desirable past. In response, states may feel a necessity to reject the past-which-is-present-here in order to achieve modern futures which already exist elsewhere. Then, particular people, places, and practices can be seen as things that need to be left behind in order to achieve the projected future; the small villages which were a traditional cornerstone of the Newfoundland and Labrador landscape are a literal example. In this way, on the periphery it becomes particularly clear how, as Bardzell has warned us [20, p. 6:15], the alternative futures embodied in speculation underwrite violence against people and ways of being deemed out of date.

\subsection{Constructing as contesting}

Within STS, distinctions are drawn between the forms of speculation that reinforce current narratives of technological progress, and 'emancipatory' approaches which question those narratives and present alternatives [129, p. 483]. This distinction is congruent with designers Dunne and Raby's imprecise but evocative distinction between 'affirmative' design, which "reinforces how things are now, [conforming] to cultural, social, technical and economic expectation," and 'critical' design, which "rejects how things are now as being the only possibility" [p. 58][70]. Here, we will argue that, instead, the unique temporal relationship set up by speculation on the periphery your present is our future - sets development projects up to be simultaneously emancipatory and conservative, affirmative and critical.

Such a mixture of emancipation with an embrace of the status quo is actually characteristic of speculation at the center, too. Speculation from the center often understands itself as revolutionary: scientists promise radically new ways of living supported by their innovations [121], while speculative designers question established futures and propose alternatives [71]. But, as we saw, technoscientific visions are grounded in past expectations of technologies, while speculative design is subject to an inherent conservatism, arising from its tactics of framing alternatives within 
exaggerated versions of the normative expectations of design [64, 174]. But the periphery generates unique circumstances for the emancipatory and the conservative to collide.

In our cases on the periphery, the most emancipatory future-making was that of Manley and the PNP in 1970s Jamaica. While their imagination of Black and national power contradicted the expectations of the US and most of the world, it was not speculative, in the sense of apparently unlikely. But when their plans were undone, and without alternatives felt to be viable, the Jamaican government changed course to a conservative strategy which adopted logics of development arising from the center. Similarly, the Smallwood government took an industrial future as existed on the mainland as a necessary given if the province were to survive; its industrialization plan was the only means it could imagine to reach that future. While these projects were certainly speculative, they were simultaneously conservative, in that they were constructing futures along given lines.

But there is something inherently emancipatory about even these projects which adopted development strategies from elsewhere. They were emancipatory, in that they imagined industrial and liberal powerhouses not just in global developed centers but also right where they were: ex-colonies on the edge of the Atlantic. Even, and perhaps especially, at their most affirmative, the projects' contortions and systemic failures lay bare the structural difficulty of peripheral places fitting into promulgated definitions of global economic success.

Wodiczko argues that in situations of gross inequality, responsible design can provide only "unacceptable and contradictory 'solutions'” [207, p. 17]. Its goal should not be to 'solve' problems but to scandalize, attracting attention to the unacceptable conditions of the design context. The scandal in these cases is that the governments of Jamaica and Newfoundland and Labrador took the ideologies of industrial and liberal development seriously. They didn't accept the unspoken truth that those ideologies were only intended to work for those at the center of the global order. Critics commonly write that Smallwood's downfall, for example, was that he believed that the centralized model of industrial development, where resources are brought to the center and shipped back as products to the periphery, could work in the periphery as well [135, p. 86]. However unintentionally, such projects demonstrate how the game is rigged.

At both the center and the periphery, then, speculation inhabits an ambiguous space that is simultaneously conservative and emancipatory. The version at the center prides itself on its innovation but rests within normative frames that limit the degree to which true change is possible The version on the periphery is conservative in that it adopts frames of innovation from the center which may not fit locally. But it is emancipatory precisely in its commitment that those frames should work there. To construct futures based on the center's standard lines on the periphery inherently contests narratives of how futures are constructed and who can be their author.

\section{CONCLUSION}

Prior work in CSCW has traced how collectively shared futures are articulated through and shape everyday practices related to technologies. Envisioned futures are used to coordinate action that shapes what technologies will be and how they will be taken up. CSCW work on speculation in the Global South in particular has begun to suggest how such future-making is taken up in fraught spaces of development. A recurring trope in this work is the complex double bind of speculation in the periphery: it is leveraged to construct futures outside of a Western hegemony, but often caught up in power geometries that unintentionally reinforce it.

Our case studies reveal a core dynamic underlying this double bind, rooted in a fundamental ambiguity in speculation between constructing and contesting futures. We show that the issues identified by researchers of the Global South are not limited to particular geographical locations but are tied to power differences between the center and the periphery. At the center, powerful stakeholders focus primarily on constructing futures. On the periphery, pressing problems also 
provide powerful incentives to construct futures. But, like it or not, their creators must simultaneously contest the apparently natural ordering of their states as 'behind,' and therefore as less authoritative architects of the future.

In the end, speculation from the periphery is constrained by economic resources and the actions of geopolitical powers. But it is simultaneously freed from long-standing narratives about how technology produces presents and futures. Innovation from the center looks like constructing futures, but on the periphery, it contests even while it constructs. Necessity leads these forms of speculation to be knitted together inventively. Our cases demonstrate how this tension leads to specific dilemmas, and to practices that resolve those dilemmas. In our cases, stakeholders addressed the pressing problems of the present by imagining audacious futures which invited citizens and other stakeholders to invest in the states' plans. These futures' fantastic elements were made to feel real by constructing coherent and compelling fictions responding to and building on realities in other places. States relegated to the past sometimes found ways to incorporate elements of that past in future visions, and other times eradicated aspects of the present understood as incompatible with the future. Even when most conservative, in copying features of narratives of the future produced elsewhere, these states moved audaciously by laying claim to those futures for themselves.

\section{ACKNOWLEDGEMENTS}

We are deeply grateful to Seyram Avle, Paul Dourish, Bill Gaver, Megh Marathe, Samir Passi, Donny Persaud, and Palashi Vaghela for suggestions that have improved this paper. Special thanks to anonymous reviewers whose detailed, generous comments led to enormous improvements in this work. Thanks to Ailsa Craig and Max Liboiron for facilitating a research visit in support of this work. This work was supported by the NSF under grants 1217685, 1908327, and 1955125, by the Memorial University of Newfoundland and Labrador Provost and VP (Academic) "Support for Scholarship in the Arts" Fund, and by the Intel Science \& Technology Center for Social Computing.

\section{REFERENCES}

[1] Vincanne Adams, Michelle Murphy, and Adele E Clarke. 2009. Anticipation: Technoscience, Life, Affect, Temporality. Subjectivity 28, 1 (Sept. 2009), 246-265. https://doi.org/10.1057/sub.2009.18

[2] Tamara Adlin, John Pruitt, Kim Goodwin, Colin Hynes, Karen McGrane, Aviva Rosenstein, and Michael J Muller. 2006. Putting personas to work. In CHI'06 Extended Abstracts on Human Factors in Computing Systems. ACM, 13-16.

[3] Syed Ishtiaque Ahmed, Steven J. Jackson, and Md Rashidujjaman Rifat. 2015. Learning to Fix: Knowledge, Collaboration and Mobile Phone Repair in Dhaka, Bangladesh. In Proceedings of the Seventh International Conference on Information and Communication Technologies and Development. 1-10.

[4] David Alexander. 1974. Development and Dependence in Newfoundland 1880-1970. Acadiensis 4, 1 (1974), 3-31.

[5] Ali Alkhatib, Michael S. Bernstein, and Margaret Levi. 2017. Examining Crowd Work and Gig Work through the Historical Lens of Piecework. In Proceedings of the 2017 CHI Conference on Human Factors in Computing Systems (CHI '17). ACM, New York, NY, USA, 4599-4616. https://doi.org/10.1145/3025453.3025974

[6] F Ambursley. 1981. Jamaica: The Demise of'Democratic Socialism'. New Left Review 128 (1981), $76-87$.

[7] Morgan G. Ames. 2018. Hackers, Computers, and Cooperation: A Critical History of Logo and Constructionist Learning. Proceedings of the ACM on Human-Computer Interaction 2, CSCW (Nov. 2018), 18:1-18:19. https://doi.org/ $10.1145 / 3274287$

[8] Reynaldo Anderson. 2016. Afrofuturism 2.0 \& the Black Speculative Arts Movement: Notes on a Manifesto. Obsidian $42,1 / 2(2016), 228-236$.

[9] Ahmed Ansari. 2015. "Design must fill current human needs before imagining new futures.". https://medium.com/ @aansari86/design-must-fi-ll-current-human-needs-before-imagining-new-futures-7a9b10815342

[10] Arjun Appadurai. 1997. Repetition. In International Conference on Time and Value. Lancaster University, Bailrigg, Lancaster, UK.

[11] Arjun Appadurai. 2015. Afterword: The Dreamwork of Capitalism. Comparative Studies of South Asia, Africa and the Middle East 35, 3 (Dec. 2015), 481-485. https://doi.org/10.1215/1089201X-3426325

[12] James Auger. 2013. Speculative design: crafting the speculation. Digital Creativity 24, 1 (2013), 11-35.

[13] James Auger and Julian Hanna. 2019. How the Future Happens. Fournal of Futures Studies 23, 3 (2019), 93-98.

Proc. ACM Hum.-Comput. Interact., Vol. 5, No. CSCW1, Article 121. Publication date: April 2021. 
[14] Seyram Avle and Silvia Lindtner. 2016. Design (Ing)'Here'and'There' Tech Entrepreneurs, Global Markets, and Reflexivity in Design Processes. In Proceedings of the 2016 CHI Conference on Human Factors in Computing Systems. 2233-2245.

[15] Seyram Avle, Silvia Lindtner, and Kaiton Williams. 2017. How Methods Make Designers. In Proceedings of the 2017 CHI Conference on Human Factors in Computing Systems. 472-483.

[16] Angelika Bammer. 1991. Partial Visions: Feminism and Utopianism in the 1970s. Routledge.

[17] Tiffany E. Barber, Nettrice Gaskins, Ricardo Guthrie, Grace Gipson, Ken McLeod, Andrew Rollins, Lonny Avi Brooks, David DeIuliis, Jeff Lohr, and Esther Jones. 2015. Afrofuturism 2.0: The Rise of Astro-Blackness. Lexington Books.

[18] Jeffrey Bardzell and Shaowen Bardzell. 2016. Humanistic HCI. interactions 23, 2 (2016), 20-29.

[19] Shaowen Bardzell. 2014. Utopias of Participation: Design, Criticality, and Emancipation. In Proceedings of the 13th Participatory Design Conference: Short Papers, Industry Cases, Workshop Descriptions, Doctoral Consortium Papers, and Keynote Abstracts-Volume 2. 189-190.

[20] Shaowen Bardzell. 2018. Utopias of Participation: Feminism, Design, and the Futures. ACM Transactions on ComputerHuman Interaction 25, 1, Article 6 (Feb. 2018), 6:1-6:24 pages. https://doi.org/10.1145/3127359

[21] Frances Bartkowski. 1991. Feminist Utopias. U of Nebraska Press.

[22] Gerhard P Bassler. 1986. "Develop or Perish": Joseph R. Smallwood and Newfoundland's Quest for German Industry, 1949-1953. Acadiensis 15, 2 (1986), 93-119.

[23] Gerhard P Bassler. 2000. Alfred Valdmanis and the Politics of Survival. University of Toronto Press.

[24] Kristina Baudemann. 2016. Indigenous Futurisms in North American Indigenous Art: The Transforming Visions of Ryan Singer, Daniel McCoy, Topaz Jones, Marla Allison, and Debra Yepa-Pappan. Extrapolation 57, 1-2 (2016) 117-150.

[25] Laura Bear, Ritu Birla, and Stine Simonsen Puri. 2015. Speculation: Futures and Capitalism in India. Comparative Studies of South Asia, Africa and the Middle East 35, 3 (2015), 387-391.

[26] Jens Beckert. 2013. Imagined Futures: Fictional Expectations in the Economy. Theory and society 42, 3 (2013), $219-240$.

[27] George Beckford. 1985. Pathways to Progress: The People's Plan for Socialist Transformation, famaica, 1977-78. Maroon Publishing House.

[28] Genevieve Bell, Mark Blythe, and Phoebe Sengers. 2005. Making by making strange: Defamiliarization and the design of domestic technologies. 12, 2 (2005), 149-173.

[29] Frans Berkhout. 2006. Normative Expectations in Systems Innovation. Technology Analysis \& Strategic Management 18, 3-4 (2006), 299-311.

[30] Xhulio Binjaku. 2018. Excrementa II: The Legitimizing Model. Limn 9 (Jan. 2018).

[31] Raymond Blake. 2015. The Resettlement of Pushthrough, Newfoundland, in 1969. Newfoundland and Labrador Studies 30, 2 (2015), 220-245.

[32] Julian Bleecker. 2009. Design Fiction: A Short Essay on Design, Science, Fact and Fiction. Near Future Laboratory 29 (2009).

[33] Mark Blythe. [n.d.]. Research through design fiction: narrative in real and imaginary abstracts. ACM Press, 703-712. https://doi.org/10.1145/2556288.2557098

[34] Mark Blythe, Andrew Monk, and Jisoo Park. 2002. Technology Biographies: Field Study Techniques for Home Use Product Development. In CHI '02 Extended Abstracts on Human Factors in Computing Systems (CHI EA '02). ACM, New York, NY, USA, 658-659. https://doi.org/10.1145/506443.506532

[35] Susanne Bødker. 1993. Historical Analysis and Conflicting Perspectives - Contextualizing HCI. In Human-Computer Interaction (Lecture Notes in Computer Science), Leonard J. Bass, Juri Gornostaev, and Claus Unger (Eds.). Springer, Berlin, Heidelberg, 1-10. https://doi.org/10.1007/3-540-57433-6_34

[36] Kirsten Boehner and Carl DiSalvo. 2016. Data, design and civics: An exploratory study of civic tech. In Proceedings of the 2016 CHI Conference on Human Factors in Computing Systems. ACM, 2970-2981.

[37] Mark Bould. 2007. The Ships Landed Long Ago: Afrofuturism and Black SF. Science Fiction Studies (2007), 177-186.

[38] Nik Brown and Mike Michael. 2003. A Sociology of Expectations: Retrospecting Prospects and Prospecting Retrospects. Technology Analysis \& strategic management 15, 1 (2003), 3-18.

[39] W. J. Browne. 1981. Eighty-Seven Years a Newfoundlander: Memoirs of William f Browne. Dicks and Company Limited, St. John's, NL, Canada.

[40] Marion Buchenau and Jane Fulton Suri. 2000. Experience prototyping. In Proceedings of the 3rd conference on Designing interactive systems: processes, practices, methods, and techniques. ACM, 424-433.

[41] C Burnett. 2013. " Unity Is Strength": Labor, Race, Garveyism, and the 1920 Panama Canal Strike. The Global South 6 , 2 (2013), 39-64.

[42] John M Carroll. 1997. Scenario-based design. In Handbook of Human-Computer Interaction (Second Edition). Elsevier, 383-406. 
[43] Ashley Carse and David Kneas. 2019. Unbuilt and Unfinished: The Temporalities of Infrastructure. Environment and Society 10, 1 (Sept. 2019), 9-28. https://doi.org/10.3167/ares.2019.100102

[44] Brenda Chalfin. 2014. Public Things, Excremental Politics, and the Infrastructure of Bare Life in Ghana's City of Tema. American Ethnologist 41, 1 (2014), 92-109.

[45] Brenda Chalfin. 2018. Excrementa III: The Leader in Upscale Sanitary Solutions? Limn 9 (Jan. 2018).

[46] Brenda Chalfin and Xhulio Binjaku. 2018. Excrementa I: Welcome to Excrementa. Limn 9 (Jan. 2018).

[47] Colin Clarke. 2016. Sovereign Jamaica: Post-Colonialism as Neocolonialism. (2016), 1-23.

[48] Newfoundland Royal Commission. 1934. Report. London: H.M. Stationery Office.

[49] Newfoundland Fisheries Development Committee. 1953. Report of the Newfoundland Fisheries Development Committee. [St. John's, NL].

[50] Parzival Copes. 1972. The Resettlement of Fishing Communities in Newfoundland. Canadian Council on Rural Development.

[51] Paul Coulton and Joseph Lindley. 2016. Game vaporware as design fictions. In Proceedings of the 20th International Academic Mindtrek Conference. ACM, 341-349.

[52] Vivian Couto and Karina Fernandez-Stark. 2018. Jamaica in the Offshore Services Global Value Chain. Technical Report. Duke Global Value Chains Center.

[53] Stephen Crocker. 2000. Hauled Kicking and Screaming into Modernity: Non-Synchronicity and Globalization in Post-War Newfoundland. Topia: Canadian Journal of Cultural Studies 3 (2000), 81-94.

[54] Jamie Cross. 2014. Dream Zones. Anticipating Capitalism and Development in India (2014).

[55] Jamie Cross. 2015. The Economy of Anticipation: Hope, Infrastructure, and Economic Zones in South India. Comparative Studies of South Asia, Africa and the Middle East 35, 3 (2015), 424-437.

[56] Declan Cullen. 2013. What to Do about Newfoundland? Colonial Reconstruction and the Commission of Government, 1933-1941. Ph.D. Dissertation. Syracuse University.

[57] Declan Cullen. 2018. Race, Debt and Empire: Racialising the Newfoundland Financial Crisis of 1933. Transactions of the Institute of British Geographers (2018).

[58] Lorenzo Davoli and Johan Redström. 2014. Materializing infrastructures for participatory hacking. In Proceedings of the 2014 conference on Designing interactive systems. ACM, 121-130.

[59] Pedro JS Vieira de Oliveira. 2016. Design at the Earview: Decolonizing Speculative Design through Sonic Fiction. Design Issues 32, 2 (2016), 43-52.

[60] Pedro JS Vieira de Oliveira and Luiza Prado de O. Martins. 1942. Decolonizing Ecologies of Time: Towards Speculative and Critical Design Practice in Latin America. (1942), 017X.

[61] Mark Dery. 1994. Black to the Future: Interviews with Samuel R. Delany, Greg Tate, and Tricia Rose. Flame wars: The discourse of cyberculture (1994), 179-222.

[62] Carl DiSalvo. 2009. Design and the Construction of Publics. Design issues 25, 1 (2009), 48-63.

[63] Carl DiSalvo. 2012. Adversarial Design. MIT Press, Cambridge, MA.

[64] Carl DiSalvo. 2012. Spectacles and Tropes: Speculative Design and Contemporary Food Cultures. The Fibreculture fournal 20: Networked Utopias and Speculative Futures (2012).

[65] Carl DiSalvo. 2014. The Need for Design History in HCI. Interactions 21, 6 (Oct. 2014), 20-21. https://doi.org/10. 1145/2669617

[66] Carl DiSalvo, Tom Jenkins, and Thomas Lodato. 2016. Designing speculative civics. In Proceedings of the 2016 CHI Conference on Human Factors in Computing Systems. ACM, 4979-4990.

[67] Carl DiSalvo, Jonathan Lukens, Thomas Lodato, Tom Jenkins, and Tanyoung Kim. 2014. Making Public Things: How HCI Design Can Express Matters of Concern. In Proceedings of the SIGCHI Conference on Human Factors in Computing Systems (CHI '14). Association for Computing Machinery, Toronto, Ontario, Canada, 2397-2406. https://doi.org/10.1145/2556288.2557359

[68] Paul Dourish and Genevieve Bell. 2011. Divining a Digital Future: Mess and Mythology in Ubiquitous Computing. Mit Press.

[69] Paul Dourish, Christopher Lawrence, Tuck Wah Leong, and Greg Wadley. 2020. On Being Iterated: The Affective Demands of Design Participation. In Proceedings of the 2020 CHI Conference on Human Factors in Computing Systems (CHI '20). Association for Computing Machinery, Honolulu, HI, USA, 1-11. https://doi.org/10.1145/3313831.3376545

[70] Anthony Dunne and Fiona Raby. 2001. Design Noir: The Secret Life of Electronic Objects. Springer Science \& Business Media.

[71] Anthony Dunne and Fiona Raby. 2013. Speculative everything: design, fiction, and social dreaming. MIT press.

[72] Malcolm Eames, William Mcdowall, Mike Hodson, and Simon Marvin. 2006. Negotiating Contested Visions and Place-Specific Expectations of the Hydrogen Economy. Technology Analysis \& Strategic Management 18, 3-4 (2006), 361-374. 
[73] Chris Elsden, David Chatting, Abigail C. Durrant, Andrew Garbett, Bettina Nissen, John Vines, and David S. Kirk. 2017. On speculative enactments. In Proceedings of the 2017 CHI Conference on Human Factors in Computing Systems. ACM, 5386-5399.

[74] Chris Elsden, Bettina Nissen, Andrew Garbett, David Chatting, David Kirk, and John Vines. 2016. Metadating: exploring the romance and future of personal data. In Proceedings of the 2016 CHI Conference on Human Factors in Computing Systems. ACM, 685-698.

[75] Bianca Elzenbaumer. 2018. Speculating with Care: Learning from an Experimental Educational Program in the West Bank. Architectural Theory Review 22, 1 (Jan. 2018), 100-119. https://doi.org/10.1080/13264826.2018.1412330

[76] Sara Eriksson and Preben Hansen. 2017. HeartBeats: A Speculative Proposal For Ritualization of Digital Objects. In Proceedings of the 2017 ACM Conference Companion Publication on Designing Interactive Systems. ACM, 218-222.

[77] Kodwo Eshun. 2003. Further Considerations of Afrofuturism. CR: The New Centennial Review 3, 2 (2003), 287-302.

[78] Terrence Farrell. 1980. Arthur Lewis and the Case for Carribbean Industrialisation. Social and Economic Studies 29, 4 (1980), 52-75. http://www.jstor.org/stable/27861908

[79] Jodi Forlizzi, John Zimmerman, Paul Hekkert, and Ilpo Koskinen. 2018. Let’s Get Divorced: Constructing Knowledge Outcomes for Critical Design and Constructive Design Research. In Proceedings of the DIS 2018 Companion Publication of the 2018 Designing Interactive Systems Conference. ACM, 395-397.

[80] Tyler Fox. 2018. Problematic Milieus: Individuating Speculative Designs. In New Directions in Third Wave HumanComputer Interaction: Volume 2-Methodologies. Springer, 155-173.

[81] Carla Freeman. 2000. High Tech and High Heels in the Global Economy: Women, Work, and Pink-Collar Identities in the Caribbean. Durham, NC : Duke University Press.

[82] Guo Freeman, Jeffrey Bardzell, and Shaowen Bardzell. 2017. Aspirational Design and Messy Democracy: Partisanship, Policy, and Hope in an Asian City. In Proceedings of the 2017 ACM Conference on Computer Supported Cooperative Work and Social Computing (CSCW '17). Association for Computing Machinery, New York, NY, USA, 404-416. https://doi.org/10.1145/2998181.2998291

[83] Suzanne Newman Fricke. 2019. Introduction: Indigenous Futurisms in the Hyperpresent Now. World Art 9, 2 (May 2019), 107-121. https://doi.org/10.1080/21500894.2019.1627674

[84] Joan H. Fujimura. 2003. Future Imaginaries: Genome Scientists as Socio-Cultural Entrepreneurs. Genetic Nature/Culture: Anthropology and Science Beyond the Two Culture Divide (2003), 176-199.

[85] Bill Gaver and Heather Martin. 2000. Alternatives: Exploring Information Appliances through Conceptual Design Proposals. In Proceedings of the SIGCHI Conference on Human Factors in Computing Systems (CHI '00). Association for Computing Machinery, The Hague, The Netherlands, 209-216. https://doi.org/10.1145/332040.332433

[86] Anthony Giddens. 2013. The Consequences of Modernity. John Wiley \& Sons.

[87] Alex Glennie and Laura Chappell. 2010. Jamaica: From Diverse Beginning to Diaspora in the Developed World. https://www.migrationpolicy.org/article/jamaica-diverse-beginning-diaspora-developed-world.

[88] Stephen Graham. 2001. 'Glocal' Infrastructure and the Splintering of Urban Economies. In Splintering urbanism networked infrastructures, technological mobilities, and the urban condition. London; New York, 304-377.

[89] Joan Greenbaum. 1988. In Search of Cooperation: An Historical Analysis of Work Organization and Management Strategies. In Proceedings of the 1988 ACM Conference on Computer-Supported Cooperative Work (CSCW'88). Association for Computing Machinery, Portland, Oregon, USA, 102-114. https://doi.org/10.1145/62266.62275

[90] Jonathan Grudin. 1990. The Computer Reaches out: The Historical Continuity of Interface Design. In Proceedings of the SIGCHI Conference on Human Factors in Computing Systems (CHI '90). ACM, New York, NY, USA, 261-268. https://doi.org/10.1145/97243.97284

[91] Jonathan Grudin. 2005. Why CHI Fragmented. In CHI '05 Extended Abstracts on Human Factors in Computing Systems (CHI EA '05). ACM, New York, NY, USA, 1083-1084. https://doi.org/10.1145/1056808.1056822

[92] Jonathan Grudin. 2006. A Missing Generation: Office Automation/Information Systems and Human-Computer Interaction. Interactions 13, 3 (May 2006), 58-61. https://doi.org/10.1145/1125864.1125900

[93] Jonathan Grudin. 2006. Turing Maturing: The Separation of Artificial Intelligence and Human-Computer Interaction. Interactions 13, 5 (Sept. 2006), 54-57. https://doi.org/10.1145/1151314.1151346

[94] Jonathan Grudin. 2018. From Tool to Partner: The Evolution of Human-Computer Interaction. In Extended Abstracts of the 2018 CHI Conference on Human Factors in Computing Systems (CHI EA '18). ACM, New York, NY, USA, Article C15, C15:1-C15:3 pages. https://doi.org/10.1145/3170427.3170663

[95] Rebecca Gulotta, William Odom, Jodi Forlizzi, and Haakon Faste. 2013. Digital artifacts as legacy: exploring the lifespan and value of digital data. In Proceedings of the SIGCHI Conference on Human Factors in Computing Systems. ACM, 1813-1822.

[96] Richard Gwyn. 2015. Smallwood: The Unlikely Revolutionary. Skyhorse Publishing, Inc.

[97] Sophie Haines. 2018. Imagining the Highway: Anticipating Infrastructural and Environmental Change in Belize. Ethnos 83, 2 (March 2018), 392-413. https://doi.org/10.1080/00141844.2017.1282974

Proc. ACM Hum.-Comput. Interact., Vol. 5, No. CSCW1, Article 121. Publication date: April 2021. 
[98] Bruce Hanington. 2003. Methods in the making: A perspective on the state of human research in design. Design issues 19, 4 (2003), 9-18.

[99] Blaine Harden. 1985. Economic Revival Eludes Jamaica. The Washington Post (Jan. 1985).

[100] Ellie Harmon and Melissa Mazmanian. 2013. Stories of the Smartphone in Everyday Discourse: Conflict, Tension \& Instability. In Proceedings of the SIGCHI Conference on Human Factors in Computing Systems. 1051-1060.

[101] J V Harries. 2015. Africa on the Moon: The Complexities of an Afrofuturist Reading of Dub. Dancecult 7, 2 (2015), 43-63.

[102] Steve Harrison, Scott Minneman, Maribeth Back, Anne Balsamo, Mark Chow, Rich Gold, Matt Gorbet, Dale Mac Donald, Kate Ehrlich, and Austin Henderson. 2001. Design: the what of XFR: eXperiments in the future of reading. 8, 3 (2001), 21-30.

[103] Steve Harrison, Phoebe Sengers, and Deborah Tatar. 2011. Making epistemological trouble: Third-paradigm HCI as successor science. Interacting with Computers 23, 5 (2011), 385-392.

[104] Sabrina Hauser, Audrey Desjardins, and Ron Wakkary. 2014. Sfuture: envisioning a sustainable university campus in 2065. In Proceedings of the 2014 companion publication on Designing interactive systems. ACM, 29-32.

[105] H G Helps. 2012. The bloody general election that changed Jamaica. Famaica Observer (Oct. 2012).

[106] H Henke. 1999. Jamaica's Decision to Pursue a Neoliberal Development Strategy: Realignments in the State-BusinessClass Triangle. Latin American Perspectives 26, 5 (Sept. 1999), 7-33.

[107] Mark E Hepworth. 1990. Geography of the information economy. New York : Guilford Press.

[108] Heritage Newfoundland \& Labrador. 2018-09-05. Was Resettlement Justified? https://www.heritage.nf.ca/articles/ politics/resettlement-analysis.php

[109] Heritage Newfoundland \& Labrador. 2018-09-15. Alfred Valdmanis. https://www.heritage.nf.ca/articles/politics/alfredvaldmanis.php

[110] Heritage Newfoundland \& Labrador. 2018-09-15. Resettlement. https://www.heritage.nf.ca/articles/politics/ resettlement.php

[111] David M Higgins and Hugh C O'Connell. 2019. Introduction: Speculative Finance/Speculative Fiction. CR: The New Centennial Review 19, 1 (2019), 1-9.

[112] Steven High. 2003. Working for Uncle Sam: The "Comings" and "Goings" of Newfoundland Base Construction Labour, 1940-1945. Acadiensis 32, 2 (2003), 84-107.

[113] Stephen Hilgartner. 2015. Capturing the Imaginary: Vanguards, Visions and the Synthetic Biology Revolution. In Science and Democracy, Clark Miller and Rob Hagendijk (Eds.). Routledge, 51-73.

[114] Nalo Hopkinson and Alondra Nelson. 2002. Making the Impossible Possible: An Interview with Nalo Hopkinson. Social Text 20, 2 (2002), 97-113.

[115] M Howland. 1993. Technological change and the spatial restructuring of data entry and processing services. Technological Forecasting and Social Change 43, 2 (1993), 185-196.

[116] Intex. 1992. Jamaican Information Services Sector Study. Technical Report. Alexandria, Virgina.

[117] Lilly Irani. 2019. Chasing Innovation: Making Entrepreneurial Citizens in Modern India. Princeton University Press.

[118] Lilly Irani, Janet Vertesi, Paul Dourish, Kavita Philip, and Rebecca E. Grinter. 2010. Postcolonial Computing: A Lens on Design and Development. In Proceedings of the SIGCHI Conference on Human Factors in Computing Systems (CHI '10). ACM, New York, NY, USA, 1311-1320. https://doi.org/10.1145/1753326.1753522

[119] Steven J. Jackson. 2014. Rethinking Repair. In Media Technologies: Essays on Communication, Materiality, and Society, Tarleton Gillespie, Pablo Boczkowski, and Kirsten Foot (Eds.). MIT Press, Cambridge, MA, 221-39.

[120] Sheila Jasanoff and Sang-Hyun Kim. 2009. Containing the Atom: Sociotechnical Imaginaries and Nuclear Power in the United States and South Korea. Minerva 47, 2 (June 2009), 119. https://doi.org/10.1007/s11024-009-9124-4

[121] Sheila Jasanoff and Sang-Hyun Kim. 2015. Dreamscapes of Modernity: Sociotechnical Imaginaries and the Fabrication of Power. University of Chicago Press.

[122] Vera Khovanskaya, Eric PS Baumer, Dan Cosley, Stephen Voida, and Geri Gay. 2013. Everybody knows what you're doing: a critical design approach to personal informatics. In Proceedings of the SIGCHI Conference on Human Factors in Computing Systems. ACM, 3403-3412.

[123] Vera Khovanskaya, Eric PS Baumer, and Phoebe Sengers. 2015. Double binds and double blinds: evaluation tactics in critically oriented HCI. In Proceedings of The Fifth Decennial Aarhus Conference on Critical Alternatives. Aarhus University Press, 53-64.

[124] Vera Khovanskaya, Phoebe Sengers, Melissa Mazmanian, and Charles Darrah. 2017. Reworking the gaps between design and ethnography. In Proceedings of the 2017 CHI Conference on Human Factors in Computing Systems. ACM, 5373-5385.

[125] Matt Kiem. 2014. Is a decolonial SCD possible? https://medium.com/@mattkiem/is-a-decolonial-scd-possible30db8675b82a 
[126] David Kirby. 2010. The future is now: Diegetic prototypes and the role of popular films in generating real-world technological development. Social Studies of Science 40, 1 (2010), 41-70.

[127] Thomas Klak and G Myers. 1998. How states sell their countries and their people. In Globalization and neoliberalism: the Caribbean context, Thomas Klak (Ed.). Rowman \&amp; Littlefield, Lanham.

[128] Kornelia Konrad. 2006. The Social Dynamics of Expectations: The Interaction of Collective and Actor-Specific Expectations on Electronic Commerce and Interactive Television. Technology Analysis \& Strategic Management 18, 3-4 (2006), 429-444.

[129] Kornelia Konrad, Harro Van Lente, Christopher Groves, and Cynthia Selin. 2016. Performing and Governing the Future in Science and Technology. In The Handbook of Science and Technology Studies, Ulrike Felt, Rayvon Fouché, Clark A. Miller, and Laurel Smith-Doerr (Eds.). MIT Press, 465-493.

[130] Sandjar Kozubaev. 2016. Stop Nigmas: Experimental Speculative Design through Pragmatic Aesthetics and Public Art. In Proceedings of the 9th Nordic Conference on Human-Computer Interaction. ACM, 76.

[131] Sandjar Kozubaev, Chris Elsden, Noura Howell, Marie Louise Juul Søndergaard, Nick Merrill, Britta Schulte, and Richmond Y. Wong. 2020. Expanding Modes of Reflection in Design Futuring. In Proceedings of the 2020 CHI Conference on Human Factors in Computing Systems (CHI '20). Association for Computing Machinery, New York, NY, USA, 1-15. https://doi.org/10.1145/3313831.3376526

[132] Shaun Lawson, Ben Kirman, Conor Linehan, Tom Feltwell, and Lisa Hopkins. 2015. Problematising upstream technology through speculative design: the case of quantified cats and dogs. In Proceedings of the 33rd Annual ACM Conference on Human Factors in Computing Systems. ACM, 2663-2672.

[133] Lucian Leahu, Steve Schwenk, and Phoebe Sengers. 2008. Subjective objectivity: negotiating emotional meaning. In Proceedings of the 7th ACM conference on Designing interactive systems. ACM, 425-434.

[134] William Lempert. 2014. Decolonizing Encounters of the Third Kind: Alternative Futuring in Native Science Fiction Film. Visual Anthropology Review 30, 2 (2014), 164-176.

[135] Douglas Mervyn Letto. 1995. Chocolate Bars and Rubber Boots: The Smallwood Industrialization Plan. Ph.D. Dissertation. Memorial University of Newfoundland.

[136] Kari Levitt. 2005. Reclaiming Development : Independent Thought and Caribbean Community. Ian Randle Publishers, Kingston; Miami.

[137] Kari Levitt. 2005. The Origins and Consequences of Jamaica's Debt Crisis, 1970-1990. In Reclaiming development : independent thought and Caribbean community. Ian Randle Publishers, Kingston; Miami, 109-182.

[138] W A Lewis. 1950. The Industrialisation of the British West Indies. Caribbean Economic Review 2, 1 (1950), 1-51.

[139] cindy lin kaiying, Silvia Lindtner, and Stefanie Wuschitz. 2019. Hacking Difference in Indonesia: The Ambivalences of Designing for Alternative Futures. In Proceedings of the 2019 on Designing Interactive Systems Conference (DIS '19). Association for Computing Machinery, San Diego, CA, USA, 1571-1582. https://doi.org/10.1145/3322276.3322339

[140] Silvia Lindtner and Seyram Avle. 2017. Tinkering with Governance: Technopolitics and the Economization of Citizenship. Proceedings of the ACM on Human-Computer Interaction 1, CSCW (2017), 1-18.

[141] Kenneth Lipartito. 2003. Picturephone and the Information Age: The Social Meaning of Failure. Technology and culture 44, 1 (2003), 50-81.

[142] Austin Lord. 2018. Speculation and Seismicity: Reconfiguring the Hydropower Future in Post-Earthquake Nepal. In Water, Technology and the Nation-State. Routledge, 167-188.

[143] Niklas Luhmann. 1993. Risk: A Sociological Theory. Transaction Publishers.

[144] Caitlin Lustig. 2019. Intersecting Imaginaries: Visions of Decentralized Autonomous Systems. Proceedings of the ACM on Human-Computer Interaction 3, CSCW (Nov. 2019), 210:1-210:27. https://doi.org/10.1145/3359312

[145] Melanie Martin. 2007. Resettlement. Newfoundland Quarterly 99, 4 (2007), 4-8.

[146] Ralph Matthews. 1975. Ethical Issues in Policy Research: The Investigation of Community Resettlement in Newfoundland. Canadian Public Policy/Analyse de Politiques (1975), 204-216.

[147] Ralph Matthews. 1976. There's No Better Place than Here: Social Change in Three Newfoundland Communities. Martin Associates.

[148] Ralph Matthews. 1986. The Outport Breakup. Horizon Canada 9 (1986), 2438-2443.

[149] Joan McFarland. 1982. Underdevelopment and Economic Theory in Atlantic Canada. Acadiensis 11, 2 (1982), $135-140$.

[150] Dennis McFarlane. 1964. A Comparative Study of Incentive Legislation in the Leeward Islands, Windward Islands, Barbados and Jamaica. Social and Economic Studies 13, 3 (1964), 1-63. http://www.jstor.org/stable/27853809

[151] Anne K. Mellor. 1982. On Feminist Utopias. Women's Studies: An Interdisciplinary fournal 9, 3 (1982), 241-262.

[152] Mike Michael. 2000. Futures of the Present: From Performativity to Prehension. Contested futures: A sociology of prospective techno-science (2000), 21-39.

[153] Mike Michael. 2012. "What Are We Busy Doing?” Engaging the Idiot. Science, Technology, \& Human Values 37, 5 (2012), 528-554.

Proc. ACM Hum.-Comput. Interact., Vol. 5, No. CSCW1, Article 121. Publication date: April 2021. 
[154] Mike Michael. 2017. Enacting Big Futures, Little Futures: Toward an Ecology of Futures. The Sociological Review (Feb. 2017).

[155] Michael Morrison. 2012. Promissory Futures and Possible Pasts: The Dynamics of Contemporary Expectations in Regenerative Medicine. BioSocieties 7, 1 (March 2012), 3-22. https://doi.org/10.1057/biosoc.2011.24

[156] Beverley Mullings. 1998. Jamaica's Information Processing Services: Neoliberal Niche or Structural Limitation? In Globalization and neoliberalism: the Caribbean context, Thomas Klak (Ed.). Rowman \& Littlefield Pub Inc, 107-122.

[157] Beverley Mullings. 1999. Sides of the Same Coin?: Coping and Resistance among Jamaican Data-Entry Operators. Annals of the Association of American Geographers 89, 2 (June 1999), 290-311.

[158] Alondra Nelson. 2000. Afrofuturism: Past-Future Visions. Color Lines 3, 1 (2000), 34-47.

[159] Alondra Nelson. 2002. Introduction: Future Texts. Social Text 20, 2 (June 2002), 1-15.

[160] Stephen Nolan. 2007. Leaving Newfoundland: A History of Out-Migration. Flanker Press, St. John's, NL.

[161] Rosemary Ommer, Peter Sinclair, John T. Pierce, and Ann Dale. 1999. Systemic Crisis in Rural Newfoundland: Can the Outports Survive? In Communities, Development, and Sustainability across Canada: Sustainability and the Environment. UBC Press, Vancouver, 49-68.

[162] Newfoundland Royal Commission on Forestry. 1955. Report of the Newfoundland Royal Commission on Forestry. [St. John's, NL].

[163] R. Pearson and S Mitter. 1993. Employment and working conditions of low-skilled information-processing workers in less developed countries. International Labour Review 132, 1 (1993).

[164] Kristin Peterson. 2014. Speculative Markets: Drug Circuits and Derivative Life in Nigeria. Duke University Press.

[165] Kavita Philip, Lilly Irani, and Paul Dourish. 2012. Postcolonial Computing: A Tactical Survey. Science, Technology, \& Human Values 37, 1 (2012), 3-29.

[166] James Phillips. 2010. Democratic Socialism, the New International Economic Order, and Globalization: Jamaica's Sugar Cooperatives in the Post-Colonial Transition. The Global South 4, 2 (2010), 178-196. http://www.jstor.org/ stable/10.2979/globalsouth.4.2.178

[167] Stanley H Pickett and Brenda E Wallis. 1972. The Evolution of Regional Planning in Newfoundland. Plan. Canada 11 (1972), 179-198.

[168] James Pierce. 2016. Design Proposal for a Wireless Derouter: Speculatively Engaging Digitally Disconnected Space. In Proceedings of the 2016 ACM Conference on Designing Interactive Systems. ACM, 388-402.

[169] James Pierce and Carl DiSalvo. 2017. Dark Clouds, Io\&\#!+, and [Crystal Ball Emoji]: Projecting Network Anxieties with Alternative Design Metaphors. In Proceedings of the 2017 Conference on Designing Interactive Systems. ACM, 1383-1393.

[170] James Pierce and Eric Paulos. 2015. Making multiple uses of the obscura 1C digital camera: reflecting on the design, production, packaging and distribution of a counterfunctional device. In Proceedings of the 33rd Annual ACM Conference on Human Factors in Computing Systems. ACM, 2103-2112.

[171] James Pierce, Phoebe Sengers, Tad Hirsch, Tom Jenkins, William Gaver, and Carl DiSalvo. 2015. Expanding and refining design and criticality in HCI. In Proceedings of the 33rd Annual ACM Conference on Human Factors in Computing Systems. ACM, 2083-2092.

[172] Planning Institute of Jamaica. 1996. National Industrial Policy: A Strategic Plan for Growth and Development. Jamaica Information Service.

[173] Luiza Prado de O. Martins. 2014. Privilege and Oppression: Towards a Feminist Speculative Design. Proceedings of DRS (2014), 980-990.

[174] Luiza Prado de O. Martins and Pedro J. S. Vieira de Oliveira. 2016. Breaking the Cycle of Macondo: Design and Decolonial Futures. XRDS: Crossroads, The ACM Magazine for Students 22, 4 (June 2016), 28-32. https://doi.org/10. 1145/2930880

[175] Luiza Prado de O. Martins and Pedro J S Vieira de Oliveira. 2014. Questioning the "critical" in Speculative \& Critical Design. https://medium.com/@luizaprado/questioning-the-critical-in-speculative-critical-design-5a355cac2ca4

[176] Kaushik Sunder Rajan. 2005. Subjects of Speculation: Emergent Life Sciences and Market Logics in the United States and India. American Anthropologist 107, 1 (2005), 19-30. https://doi.org/10.1525/aa.2005.107.1.019

[177] Catherine S. Ramírez. 2008. Afrofuturism/Chicanafuturism: Fictive Kin. Aztlán: A fournal of Chicano Studies 33, 1 (2008), 185-194.

[178] Ronald Reagan. 1982. Remarks to the Permanent Council of the Organization of American States on the Caribbean Basin Initiative.

[179] Stuart Reeves. 2012. Envisioning Ubiquitous Computing. In Proceedings of the SIGCHI Conference on Human Factors in Computing Systems (CHI '12). ACM, New York, NY, USA, 1573-1582. https://doi.org/10.1145/2207676.2208278

[180] R Schware and S Hume. 1996. Prospects for Information Service Exports from the English-Speaking Caribbean. Technical Report. 
[181] James C. Scott. 1998. Seeing Like a State: How Certain Schemes to Improve the Human Condition Have Failed. Yale University Press.

[182] Elke Seefried. 2014. Steering the Future. The Emergence of "Western" Futures Research and Its Production of Expertise, 1950s to Early 1970s. European Fournal of Futures Research 2, 1 (Dec. 2014), 1-12. https://doi.org/10.1007/s40309-013 0029-y

[183] Mimi Sheller. 2009. Infrastructures of the imagined island: software, mobilities, and the architecture of Caribbean paradise. Environment and Planning A 41, 6 (2009), 1386-1403.

[184] Edward Shils. 1975. Center and Periphery. University of Chicago Press, Chicago.

[185] Gerald M Sider. 2003. Between History and Tomorrow: Making and Breaking Everyday Life in Rural Newfoundland. Vol. 1. University of Toronto Press.

[186] AbdouMaliq Simone. 2011. Deals with Imaginaries and Perspectives: Reworking Urban Economies in Kinshasa. Social Dynamics 37, 1 (2011), 111-124.

[187] S Singh. 2004. Resistance, Essentialism, and Empowerment in Black Nationalist Discourse in the African Diaspora: A Comparison of the Back to Africa, Black Power, and Rastafari Movements. Fournal of African American Studies 8, 3 (2004), 18-36.

[188] Stephanie B. Steinhardt and Steven J. Jackson. 2015. Anticipation Work: Cultivating Vision in Collective Practice. In Proceedings of the 18th ACM Conference on Computer Supported Cooperative Work \& Social Computing (CSCW'15). Association for Computing Machinery, New York, NY, USA, 443-453. https://doi.org/10.1145/2675133.2675298

[189] Rosemary Steup, Lynn Dombrowski, and Norman Makoto Su. 2019. Feeding the World with Data: Visions of Data-Driven Farming. In Proceedings of the 2019 on Designing Interactive Systems Conference. 1503-1515.

[190] Carl Stone. 1985. Jamaica in crisis: from socialist to capitalist management. International fournal (1985), 1-30.

[191] Miriam Sturdee, Paul Coulton, Joseph G Lindley, Mike Stead, Haider Ali, and Andy Hudson-Smith. 2016. Design fiction: How to build a Voight-Kampff machine. In Proceedings of the 2016 CHI Conference Extended Abstracts on Human Factors in Computing Systems. ACM, 375-386.

[192] Frances Peace Sullivan. 2014. "Forging Ahead" in Banes, Cuba. New West Indian Guide / Nieuwe West-Indische Gids 88, 3-4 (Jan. 2014), 231-261.

[193] Marie Louise Juul Søndergaard. 2017. Intimate Design: Designing Intimacy As a Critical-Feminist Practice. In Proceedings of the 2017 CHI Conference Extended Abstracts on Human Factors in Computing Systems. ACM, 320-325.

[194] Leila Takayama. 2017. The Motivations of Ubiquitous Computing: Revisiting the Ideas behind and beyond the Prototypes. Personal Ubiquitous Comput. 21, 3 (June 2017), 557-569. https://doi.org/10.1007/s00779-017-1002-8

[195] Cameron Tonkinwise. 2014. How we intend to future: Review of Anthony Dunne and Fiona Raby, Speculative Everything: Design, Fiction, and Social Dreaming. Design Philosophy Papers 12, 2 (2014), 169-187.

[196] Cameron Tonkinwise. 2015. Just design: Being dogmatic about defining speculative critical design future fiction. Experimental thinking/design practices. Brisbane: Griffith University Art Gallery (2015).

[197] Khai N Truong, Gillian R Hayes, and Gregory D Abowd. 2006. Storyboarding: an empirical determination of best practices and effective guidelines. In Proceedings of the 6th conference on Designing Interactive systems. ACM, 12-21.

[198] Unknown. 1980. The Havana Summit. Third World Quarterly 2, 2 (1980), 328-338. http://www.jstor.org/stable/3991453

[199] Unknown. n.d.. On the Move in Newfoundland. Profile: Regional Economic Expansion 1, 6 (n.d.).

[200] Max Van Kleek, Dave Murray-Rust, Amy Guy, Kieron O’hara, and Nigel Shadbolt. 2016. Computationally mediated pro-social deception. In Proceedings of the 2016 CHI Conference on Human Factors in Computing Systems. ACM, 552-563.

[201] Sherryl Vint. 2019. Promissory Futures: Reality and Imagination in Finance and Fiction. CR: The New Centennial Review 19, 1 (2019), 11-36.

[202] Kelly Vodden, Greg Halseth, Sean Patrick Markey, and David Bruce. 2010. Heroes, Hope, and Resource Development in Canada's Periphery: Lessons from Newfoundland and Labrador. In The next Rural Economies: Constructing Rural Place in Global Economies.

[203] T Weis. 2005. A precarious balance: Neoliberalism, crisis management, and the social implosion in Jamaica. Capital \& Class 29, 1 (Jan. 2005), 115-147.

[204] Robert Wells. 1960. Report on Resettlement in Newfoundland. Province of Newfoundland.

[205] Woodrow W. Winchester, III. 2018. Afrofuturism, Inclusion, and the Design Imagination. Interactions 25, 2 (Feb. 2018), 41-45. https://doi.org/10.1145/3182655

[206] Woodrow W. Winchester III. 2019. Engaging the Black Ethos: Afrofuturism as a Design Lens for Inclusive Technological Innovation. Journal of Futures Studies 24, 2 (2019), 55-62.

[207] Krzysztof Wodiczko. 1999. Critical vehicles: writings, projects, interviews. MIT press.

[208] Ytasha Womack. 2013. Afrofuturism: The World of Black Sci-Fi and Fantasy Culture. Chicago Review Press.

[209] Richmond Y. Wong and Steven J. Jackson. 2015. Wireless Visions: Infrastructure, Imagination, and US Spectrum Policy. In Proceedings of the 18th ACM Conference on Computer Supported Cooperative Work \& Social Computing (CSCW'15). 
Association for Computing Machinery, New York, NY, USA, 105-115. https://doi.org/10.1145/2675133.2675229

[210] Richmond Y. Wong and Vera Khovanskaya. 2018. Speculative Design in HCI: From Corporate Imaginations to Critical Orientations. In New Directions in Third Wave Human-Computer Interaction: Volume 2 - Methodologies, Michael Filimowicz and Veronika Tzankova (Eds.). Springer International Publishing, Cham, 175-202. https://doi.org/10. 1007/978-3-319-73374-6_10

[211] Richmond Y. Wong, Vera Khovanskaya, Sarah E. Fox, Nick Merrill, and Phoebe Sengers. 2020. Infrastructural Speculations: Tactics for Designing and Interrogating Lifeworlds. In Proceedings of the 2020 CHI Conference on Human Factors in Computing Systems (CHI '20). Association for Computing Machinery, New York, NY, USA, 1-15. https://doi.org/10.1145/3313831.3376515

[212] Richmond Y Wong, Deirdre K Mulligan, Ellen Van Wyk, James Pierce, and John Chuang. 2017. Eliciting Values Reflections by Engaging Privacy Futures Using Design Workbooks. (2017).

[213] Miriam Carol Wright. 2001. A Fishery for Modern Times: The State and the Industrialization of the Newfoundland Fishery, 1934-1968. University of Toronto Press.

[214] Susan Wyche, Phoebe Sengers, and Rebecca E. Grinter. 2006. Historical Analysis: Using the Past to Design the Future. In Proceedings of the 8th International Conference on Ubiquitous Computing (UbiComp'06). Springer-Verlag, Berlin, Heidelberg, 35-51. https://doi.org/10.1007/11853565_3

[215] Lisa Yaszek. 2006. Afrofuturism, Science Fiction, and the History of the Future. Socialism and Democracy 20, 3 (2006) 41-60.

[216] Paulina Yurman. 2017. Designing for Ambivalence: Mothers, Transitional Objects and Smartphones. In Proceedings of the 2017 CHI Conference Extended Abstracts on Human Factors in Computing Systems. ACM, 344-348.

Received June 2020; revised October 2020; accepted December 2020 